\title{
WATER QUALITY PERFORMANCE OF A RECIPROCATING BIOFILM REACTOR FOR TREATMENT OF DAIRY WASTEWATER
}

\author{
A Thesis \\ presented to \\ the Faculty of California Polytechnic State University, \\ San Luis Obispo
}

\author{
In Partial Fulfillment \\ of the Requirements for the Degree \\ Master of Science in Civil and Environmental Engineering
}

by

Jason Patrick Kane

December 2010 
(C) 2010

Jason Patrick Kane

ALL RIGHTS RESERVED 


\section{COMMITTEE MEMBERSHIP}

TITLE:

Water quality performance of a reciprocating biofilm

reactor for treatment of dairy wastewater

AUTHOR: $\quad$ Jason Patrick Kane

DATE SUBMITTED: December 2010

COMMITTEE CHAIR: $\quad$ Dr. Tryg Lundquist, Assistant Professor, Civil \&

Environmental Engineering

COMMITTEE MEMBER: Dr. Bruce Golden, Department Head and Professor, Dairy

Science

COMMITTEE MEMBER: Dr. Yarrow Nelson, Professor, Civil \& Environmental

Engineering 


\begin{abstract}
Water quality performance of a reciprocating biofilm reactor

for treatment of dairy wastewater
\end{abstract}

Jason Patrick Kane

Removal of organic matter and nitrogen from concentrated wastewaters is often a complex and costly process that is rarely implemented in animal agriculture, such as the dairy industry, despite regulatory pressures and the high cost of land for manure application in some regions. This paper describes results from the first implementation for treatment of dairy farm wastewater of the relatively simple ReCip ${ }^{\circledR}$ technology. ReCip ${ }^{\circledR}$ typically consists of two basins filled with rock aggregate through which wastewater is flowed in series. One basin is full of wastewater and the other is only partially full. Wastewater is alternately pumped between the basins (reciprocated), which exposes biofilm on the aggregate to air and then submerges it, repeatedly creating aerobic and then anoxic conditions. These conditions promote nitrification and denitrification, in addition to removal of organic matter through biodegradation. The present study reports on 149 days of operation of a pilot-scale $\mathrm{ReCip}^{\circledR}$ system treating anaerobic lagoon wastewater at a California flush dairy. The resulting removals of wastewater constituents were $94 \%$ of total ammonia nitrogen (TAN), $49 \%$ of total nitrogen, $56 \%$ of five-day carbonaceous biological oxygen demand, and $61 \%$ of total suspended solids. A simple mathematical model, which considers influent TAN concentration and temperature, was capable of predicting TAN removal. Preliminary results of air quality emission monitoring indicate releases of nitrous oxide, methane, and carbon dioxide from the 
basins during system operation. Additional studies are currently underway to further quantify air emissions, test various $\operatorname{ReCip}^{\circledR}$ operating conditions, and develop scale-up cost estimates. 


\section{ACKNOWLEDGMENTS}

Dr. Tryg Lundquist - Your energy and enthusiasm are inspirational. Thanks for giving an unknown SDSU graduate the amazing opportunity to work on this project and become part of the Cal Poly community. You are an incredible mentor and friend.

Dr. Yarrow Nelson - The first professor I ever had at Cal Poly, who upon becoming a professor took a seminar on being an effective teacher, unheard of at the time. Thanks for the support and willingness to lend an open ear.

Dr. Bruce Golden - Our liaison to the dairy who was instrumental to the construction and operation of this project. Thanks for making the dairy and its excellent staff accessible to us non-farming folk.

USEPA, Region 9 - Provided the funding for the ReCip pilot plant construction via Sustainable Conservation, Inc.

Joe Choperena, Sustainable Conservation, Inc. - Your patience and understanding kept this project alive. Thanks for always being there and the willingness to lend a helping hand.

Drs. Frank Mitloehner and Yong Zhao, U.C. Davis - Thanks for your efforts in planning and executing the air quality testing. We were privileged to have your expertise working on this project.

Dr. Les Behrends - The inventor of ReCip. Thanks for paving the way and your continuous interest in the project.

Tennessee Valley Authority - TVA licensed the technology for use at Cal Poly.

Advanced Drainage Systems, Inc. - Provided materials for construction.

Doug Kuentzel, Cal Poly Facilities - We appreciated your conscientious efforts during the construction and the assistance of the Cal Poly Facilities personnel who helped with aspects of the construction.

Rich Silacci, Cal Poly Herd Manager - Thanks for your assistance and understanding, and for allowing us to easily integrate our research into the daily operations of the dairy farm.

Craig Stubler, Earth and Soil Science Department - Thanks for your assistance analyzing solids samples.

Seppi - Wind, rain, or darkness, the cows will be pooping. Your reliability and flexibility made working with you on this project a true delight. Don't know what I would have done without you. Viva los Gigantes.

Ruth, Dan, Fooks, and Neal - Thanks for your time and help learning methods, troubleshooting those pesky machines, and collecting data (see Murphy's Law). 
Maggie, Matt, Mike, Paul, and my other colleagues - It was awesome to get to come to school and mingle with you all. Thanks for the laughs and help in the lab.

Andry Gonzalez, Kay Kibbe, Ron Leverett, and Xi Shen - The unsung heroes. Without your help the civil and environmental machine that we have all come to love would simply fail.

Mom, Dad, and Heather - Your love and support made coming to Cal Poly an easy decision. Thanks for always being there.

Kelly - Saving the best for last. If not for this project, I would have never been lucky enough to "get on your radar." Thanks for coming along on all those trips to the lab and dairy. You are my best friend and partner in crime. 


\section{TABLE OF CONTENTS}

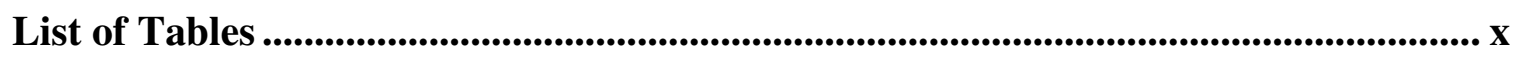

List of Figures............................................................................................................................... xi

1. INTRODUCTION

2. MATERIALS AND METHODS ............................................................................. 5

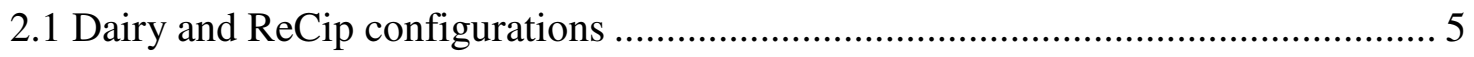

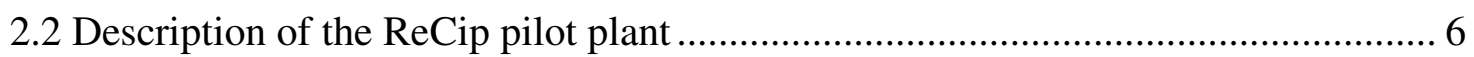

2.3 Reciprocation schedule, influent flow, and precipitation ...................................... 8

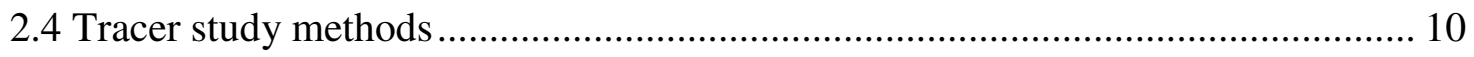

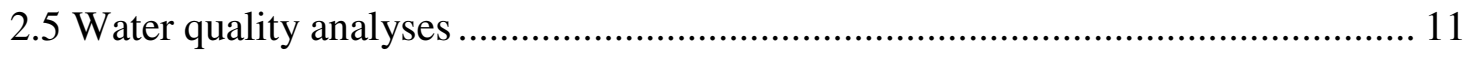

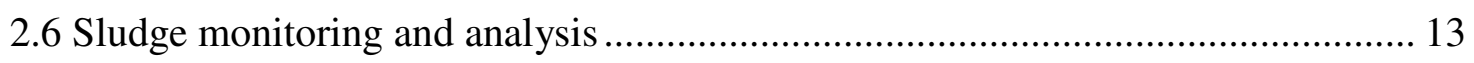

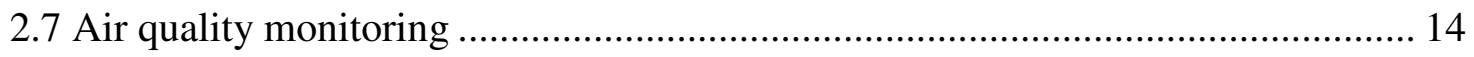

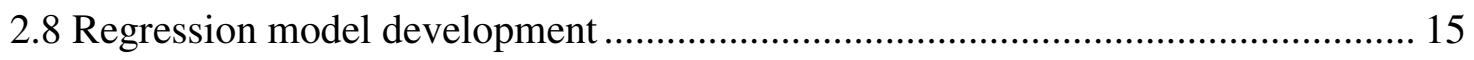

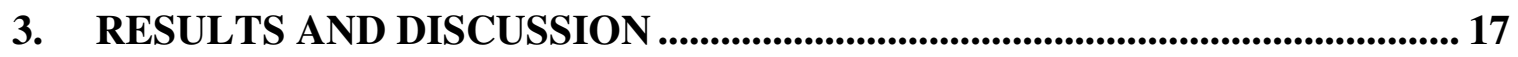

3.1 TAN removal during 149-d period ..................................................................... 17

3.2 Detailed water quality analyses and nitrogen removal during $65-\mathrm{d}$ period ............ 18

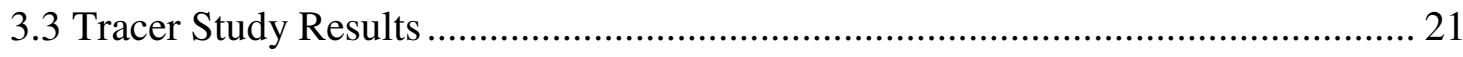

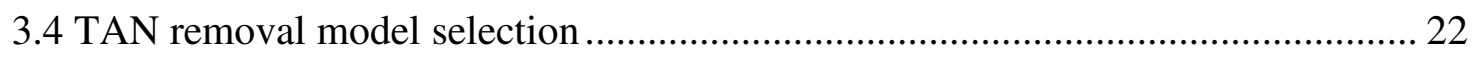

3.5 Sludge accumulation and analysis .................................................................... 24

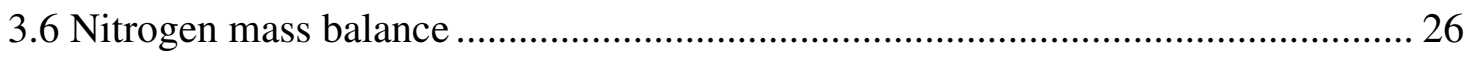

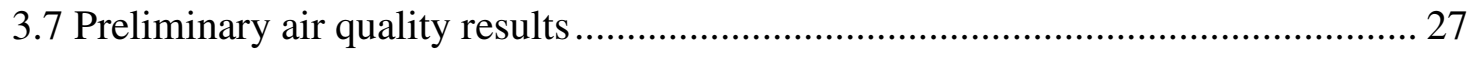




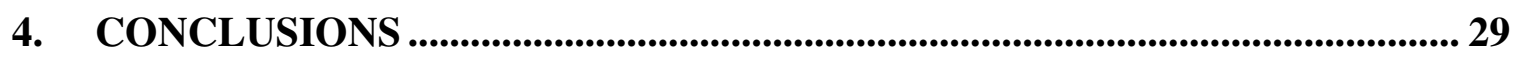

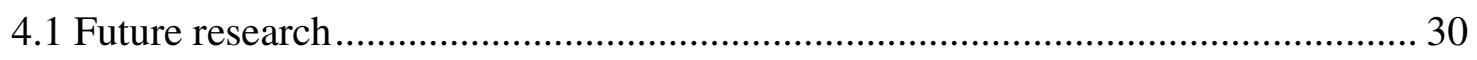

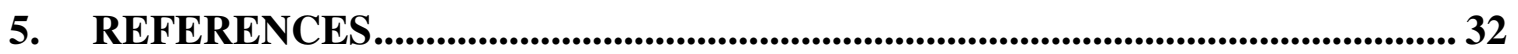

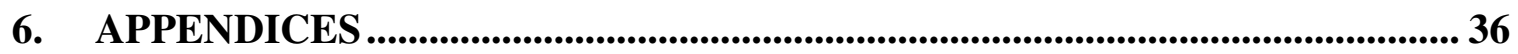

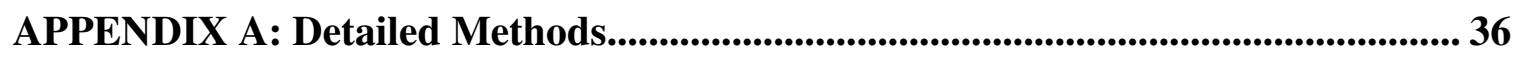

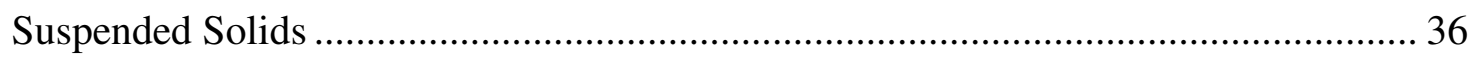

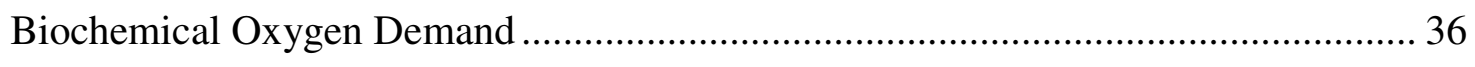

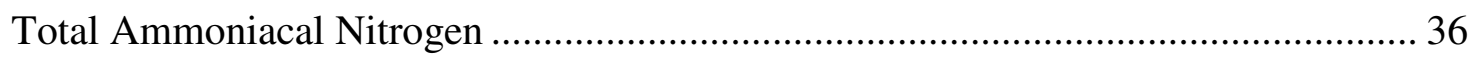

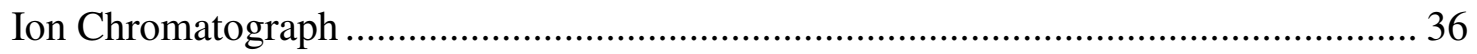

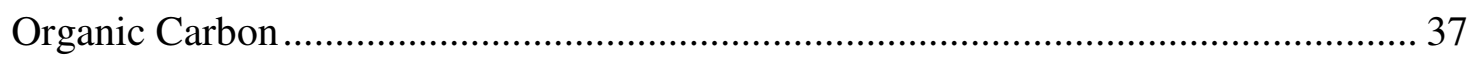

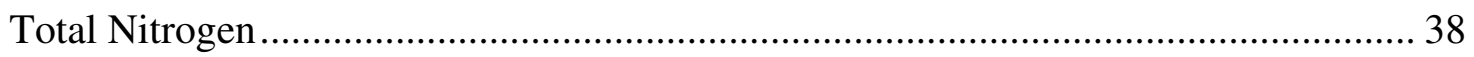

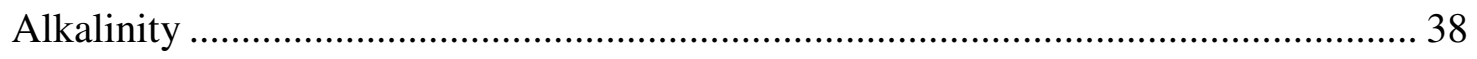

Temperature and Dissolved Oxygen.................................................................... 38

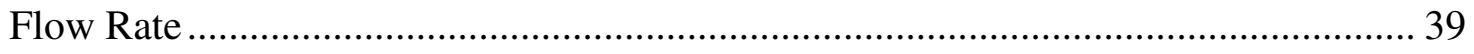

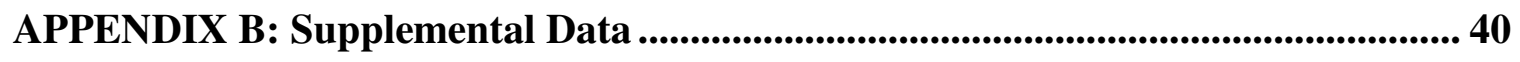

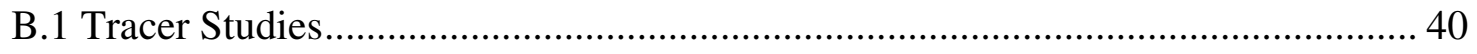

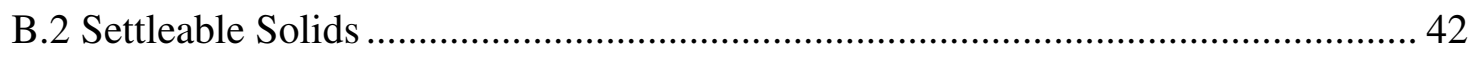

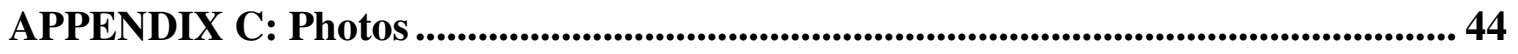




\section{List of Tables}

Table 1. Reciprocation pumping schedule, which was repeated every two hours. 9

Table 2. Dates of precipitation events $(>0.5 \mathrm{~cm} / \mathrm{d})$ during $149-\mathrm{d}$ period. Volume of rainfall entering basins, percent of influent flow during precipitation event, and affected sampling dates due to dilution caused by precipitation.

Table 3. Influent and effluent water quality results from weekly grab samples during the 149-d experiment (mean $+/$ - standard deviation; $\mathrm{n}=20$ ).

Table 4. Influent and effluent water quality results from weekly grab samples during the 65- $d$ experiment (mean $+/$ - standard deviation; $n=9$ ). 18

Table 5. Coefficient of determinants $\left(\mathrm{R}^{2}\right)$, fitting parameters $(\alpha, \beta)$, and Arrheniustype adjustment factors of TAN removal models for the $149-\mathrm{d}$ period. $\mathrm{R}^{2}$ values from calculated-versus-observed correlation.

Table 6. Sludge accumulation monitoring data. Based on average sludge depths of 15 standpipes

Table 7. Average sludge levels and composition ( $\% \mathrm{~N}$ and $\% \mathrm{C}$ of TS) in each basin during 149-d experiment.

Table 8. Percent removal of selected constituents of three ReCip systems. For the

Cal Poly dairy results are from 24 February 2010 to 29 April 2010. 28

Table B.1. Summaries of Rhodamine WT fluorescent dye tracer studies. Calculated MHRT based on estimation of time for $50 \%$ of dye to exit system based on extrapolations of effluent concentration decay. 40

Table B.2. Settleable solids data. Measured using 1-L Imhoff cone after one hour of settling....... 


\section{List of Figures}

Figure 1. Schematic of the recirculation of wastewater at the Cal Poly dairy ................... 6

Figure 2a. Cross sectional view of a portion of the ReCip basins .................................. 7

Figure 2b. Simplified plan view of the ReCip basins...................................................... 8

Figure 3a. Influent nitrogen composition from 24 Feb 2010 to 29 Apr 2010................ 20

Figure 3b. Effluent nitrogen composition from 24 Feb 2010 to 29 Apr 2010................. 20

Figure 4. Fitted and predicted periods using the linear TAN removal model ................. 23

Figure 5. Nitrogen mass balance based on the detailed water quality analyses during

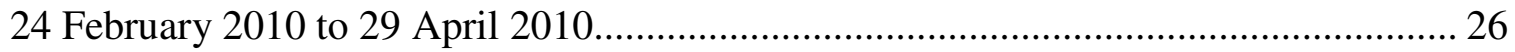

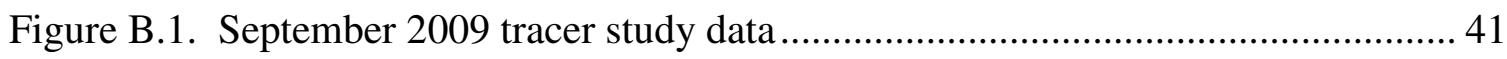

Figure B.2. June 2010 tracer study data...................................................................... 42

Figure C.1. Completed, empty basins. View from solids separation screen. ................. 44

Figure C.2. View of completed basins from ground level.............................................. 44

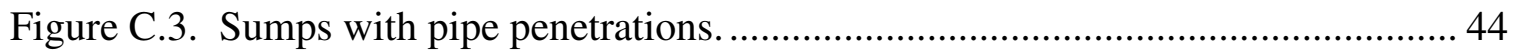

Figure C.4. Installation of Biodiffuser leach field chambers........................................... 44

Figure C.5. Installation of standpipes into leach field chambers................................... 45

Figure C.6. Completed leach field chamber installation................................................ 45

Figure C.7. View of leach field chamber network from solid separation screen............. 45

Figure C.8. Leach field chamber network along western wall. ....................................... 45

Figure C.9. Weir box in south tank near sump.......................................................... 46

Figure C.10. Effluent pipe connecting to effluent weir................................................... 46

Figure C.11. Pipe penetrations connecting leach field chambers to outside of basins.... 46

Figure C.12. Basin 2 after installation of two rock layers............................................ 46 
Figure C.13. Completed ReCip system................................................................ 47 


\section{Introduction}

The California dairy industry faces the challenge of complying with air and water quality regulations at the regional, state, and federal levels. Industry-wide on-farm environmental compliance costs are estimated to be hundreds of millions of dollars in the state of California alone (McKinsey, 2006). Since 1975, the number of dairy cows in California has doubled, while the number of dairy farms has decreased by a half (SJVP, 2005). The resulting high density of dairy cattle and encroaching urban populations have led to many dairies having insufficient access to cropland for agronomic application of manure nutrients (SJVP, 2005). In the San Joaquin Valley, home to $75 \%$ of California's dairy cattle, each dairy is required to apply manure according to a regulatory agencyapproved Nutrient Management Plan (NMP), which addresses the transport of nutrients (nitrogen, potassium, and phosphorus) in water through runoff into surface and groundwater aquifers (Moss, 2007). Farms that have inadequate cropland acreage must invest in alternatives to meet current and future regulations. Alternatives such as exporting manure off-farm, herd reduction, and land acquisition are often economically unfavorable (SJVP, 2005). Other options are to develop and implement better manure treatment systems (SJVP, 2005) or methods to recover nutrients in concentrated forms, which can be exported as fertilizer (USDA, 2008). Although requiring initial investment for research, development, and implementation, dairies with wastewater treatment systems may benefit financially in the long-term by avoiding larger environmental mitigation costs (McKinsey, 2006). An existing simple technology, already shown effective for removal of organic matter and ammonium from high strength anaerobic wastewater, is the so-called reciprocating sub-surface flow constructed wetland or 
biofilm reactor (ReCip ${ }^{\circledR}$; US Patent No. 5,863,433, Behrends 1999). ReCip was

developed at the Tennessee Valley Authority in the 1990s originally as an alternative way to improve performance of subsurface-flow constructed treatment wetlands. Since that time, ReCip has been shown to be effective in the treatment of swine lagoon water (Rice and Humenik, 2004), as well as industrial and municipal wastewaters (Behrends et al., 2003). For dairies that collect manure with a water flushing system (as opposed to solids scraping), ReCip may be a desirable option for managing nitrogen and excess dissolved organic matter.

ReCip consists of at least two paired basins filled with a rock aggregate substrate. At the start of a "reciprocation" cycle, one basin is mostly empty. Wastewater from the full basin is pumped into the empty basin, and then after a specific pause, the direction of pumping is reversed, completing the cycle. In addition to reciprocation, influent wastewater is pumped into the first basin (Basin 1), usually continuously. During the Basin 1-to-Basin 2 reciprocation pumping, the wastewater influent is mostly transferred to Basin 2. Effluent leaves Basin 2 by overflowing a weir. Reciprocation causes biofilm on the aggregates to be alternately exposed to air and to wastewater which creates cyclic aerobic and anoxic environments promoting oxidation of organic matter, nitrification, and denitrification. Other treatment mechanisms operating in the ReCip system include sedimentation of solids, anaerobic digestion, and minor ammonia volatilization.

ReCip overcomes the oxygen limitation on nitrification that is common in traditional subsurface flow constructed wetlands (Crites and Tchobanoglous, 1998; Kadlec and Knight, 1996; USEPA, 1993). With ReCip, recurrent drain cycles resulting from reciprocation draw atmospheric oxygen into the basin, exposing the liquid films 
surrounding the biofilms to atmospheric oxygen (Behrends et al., 1993). During this phase, oxygen diffuses into the biofilm where microorganisms compete for oxygen as their electron acceptor, oxidizing organic matter or nitrifying ammoniacal nitrogen into nitrate (Halling-Sørensen and Jørgensen, 1993). According to biofilm theory, an oxygen gradient, with lower oxygen concentrations closer to the rock substrate, develops in the biofilm. Nitrate, which becomes the favored electron acceptor in the anoxic layer adjacent to the rock substrate, is denitrified. Simultaneously, the biofilm in the adjacent basin is submerged and the oxygen dissolved in its biofilm is partially transferred into the pore water. While dissolved oxygen is present, organic matter removal and nitrification are promoted, followed by denitrification once the pore water becomes anoxic. Reciprocation is programmed to occur multiple times each day depending on the pollutant loading, treatment objectives, and temperature (Behrends et al., 2001). In animal production settings, barn flush water could be mixed with ReCip effluent in a lagoon, promoting denitrification and odor oxidation. Most lagoon water would be disposed of by irrigation. Alternatively, ReCip effluent could be collected in a segregated reservoir for barn flushing, resulting in more sanitary conditions in the barns compared to conventional lagoon water flushing.

The goal of this research was to determine the effectiveness of ReCip for oxidizing ammoniacal nitrogen and removing total nitrogen and organic matter from dairy lagoon water. A pilot-scale ReCip system was constructed at the dairy farm of the California Polytechnic State University, San Luis Obispo (Cal Poly), becoming operational in November 2009. The lagoon water was recycled repeatedly for barn flushing. Weekly water quality analyses of influent and effluent samples determined 
treatment effectiveness of the ReCip process. A nitrogen mass balance to analyze nitrogen removal was calculated using water quality results and monthly sludge compositional analysis. The rate and spatial pattern of sludge accumulation was monitored to analyze the potential impacts of sludge accumulation in the system. If proven effective in the treatment of nitrogen and organic matter, ReCip could be implemented on dairy farms with flush manure collection and storage systems, thereby reducing the cropland acreage needed for irrigation at agronomic rates. 


\section{Materials and Methods}

\subsection{Dairy and ReCip configurations}

Lagoons at the Cal Poly dairy provided influent water for the ReCip pilot plant. The lagoons are mostly drained during summer irrigation and are refilled over the course of the year, primarily with clean water used to flush the milking parlor and storm water. During the study, the free-stall barns housed an average of about 325 animal units $(1,000$ lbs each) consisting of lactating cows, dry cows, heifers, and calves. Flush water from the free-stall barns passed through pretreatment steps: a sand trap settling basin, an elevated inclined screen, and a second settling basin before entering one of the two storage lagoons (Figure 1). Composted solids from the inclined screen were used as bedding in the free-stall barns. Clean water entering the wastewater flow of the dairy was comprised of $91 \mathrm{~m}^{3} / \mathrm{d}(24,000 \mathrm{gal} / \mathrm{d})$ for flushing the milking parlor and about $30 \mathrm{~m}^{3} / \mathrm{d}$ $(8,000 \mathrm{gal} / \mathrm{d})$ used in the free-stall barns. Winter rainfall was also collected from the exercise pens and directed to the lagoons. Four times per day, $57 \mathrm{~m}^{3}$ (15,000 gal) of lagoon water were used to flush the free-stall barns.

Lagoon water was pumped into Basin 1 of the ReCip using a Flex-i-liner ${ }^{\circledR}$ rotary peristaltic pump (Vanton Pump and Equipment Corp., Hillside, New Jersey) housed on the lagoon shore. The pump inlet connected to a $15-\mathrm{m}$ long, 3-cm diameter tube that was suspended $0.3-\mathrm{m}$ below the lagoon water surface from a raft enclosed in a coarse plastic screen. 


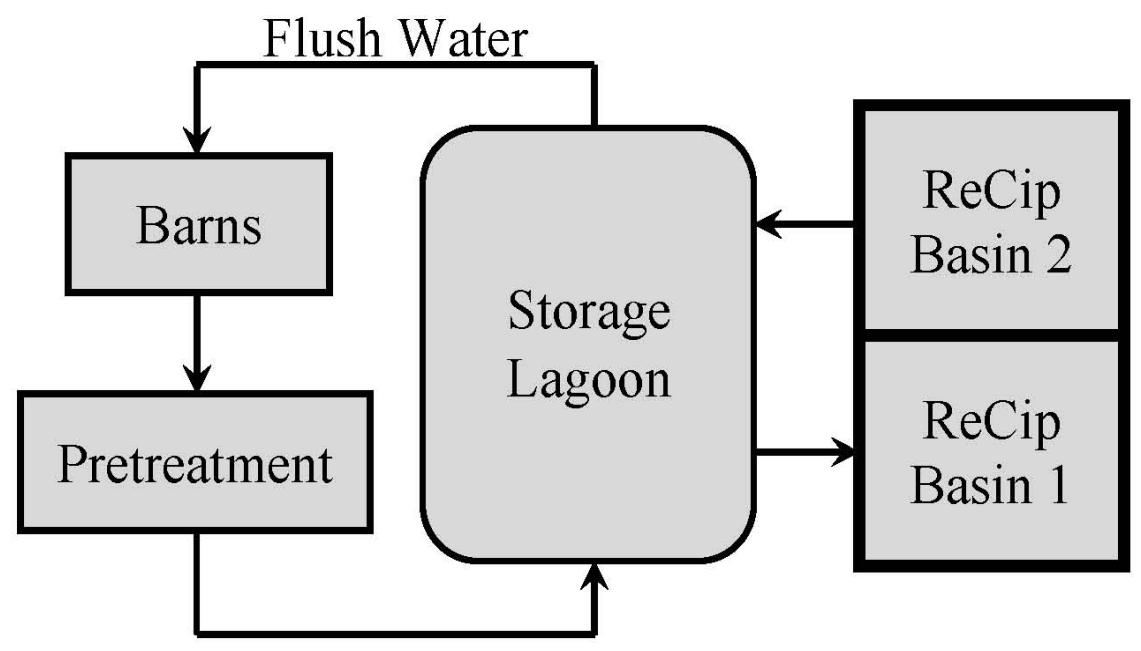

Figure 1. Simplified schematic of the recirculation of wastewater at the Cal Poly dairy. Anaerobic storage lagoon wastewater was used to flush the free-stall barns. A pump delivered influent to the ReCip pilot plant, and effluent was discharged back into lagoon.

\subsection{Description of the ReCip pilot plant}

The ReCip was comprised of two adjacent vertical-wall concrete basins each with the dimensions of $11.0 \mathrm{~m}$ x $6.1 \mathrm{~m} \times 1.3-\mathrm{m}$ deep ( $36 \mathrm{ft} \times 20 \mathrm{ft} \times 4.3 \mathrm{ft}$ ). On the floor of each basin, five rows of arched plastic chambers, typically used in septic tank leach fields (BioDiffuser ${ }^{\mathrm{TM}}$ Model 1600BD, Advanced Drainage Systems, Inc., Hillard, Ohio), were laid out in channels connected to ports in the basin walls. The arched chambers had horizontally slotted walls. These channels and ports will allow accumulated sludge to be flushed out in the future. Three 10-cm diameter standpipes were installed along each channel for monitoring of sludge depth and composition. The standpipes were spaced 1.5 $\mathrm{m}$ from the wall and $4.0 \mathrm{~m}$ from each other. Between each channel, standpipes were spaced $0.8 \mathrm{~m}$ from the wall and $1.1 \mathrm{~m}$ from each other. The standpipes were supported on thin legs, which allowed the sludge blanket to pass under them.

A $30-\mathrm{cm}$ thick layer of greywacke cobblestone (15- to $25-\mathrm{cm}$ diameter) was installed around the floor channels. The next layer was $23 \mathrm{~cm}$ of crushed granitic rock 
(5- to $10-\mathrm{cm}$ diameter). The top layer was $64 \mathrm{~cm}$ of crushed granitic rock (2- to $4-\mathrm{cm}$ diameter). The water level cycled between 15 and $91 \mathrm{~cm}$ from the floor (Figure 2a).

Weir boxes (Agri Drain, Adair, Iowa) for water level control were installed in Basin 2 near the sump and at the effluent pipe (Figure $2 b$ ). The weir box near the sump (not shown) had its inlet connected through the central wall to the Basin 1 sump. The outlet of this weir box opened into Basin 2. Effluent was discharged from the system though the weir box (Box C) connected to the effluent pipe.

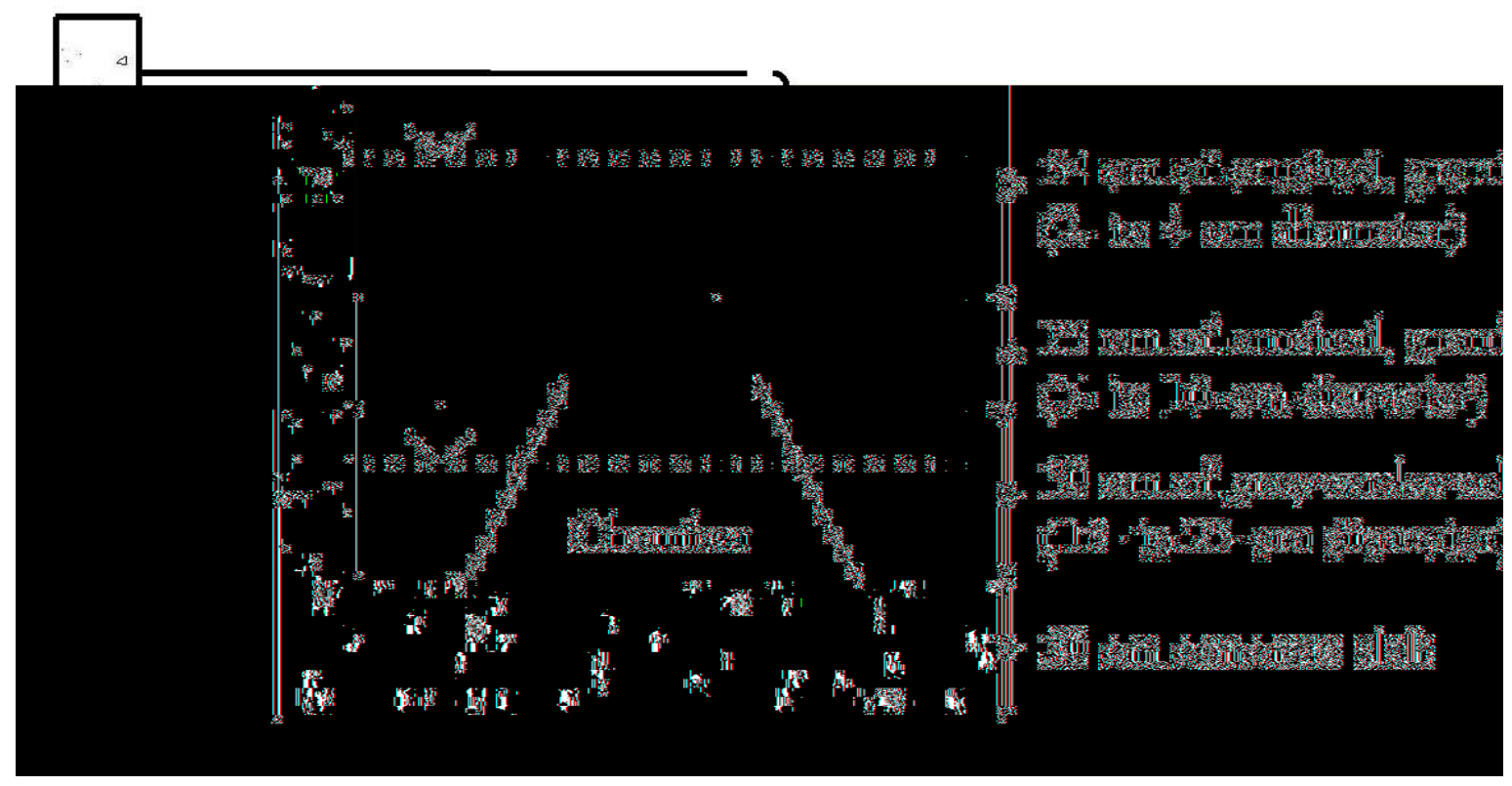

Figure 2a. Cross sectional view of a portion of the ReCip basins, showing the cross section of a leach field chamber. The dashed lines indicate high and low water levels at 91 and $15 \mathrm{~cm}$, respectively. Solid lines indicate the boundaries of the rock layers. Layer thickness, rock type, and rock diameter are listed next to each layer.

Chambers collected sludge and provided ports for sludge monitoring through standpipes (not shown). Note: Full-scale installations could use lined earthen basins instead of concrete basins. 


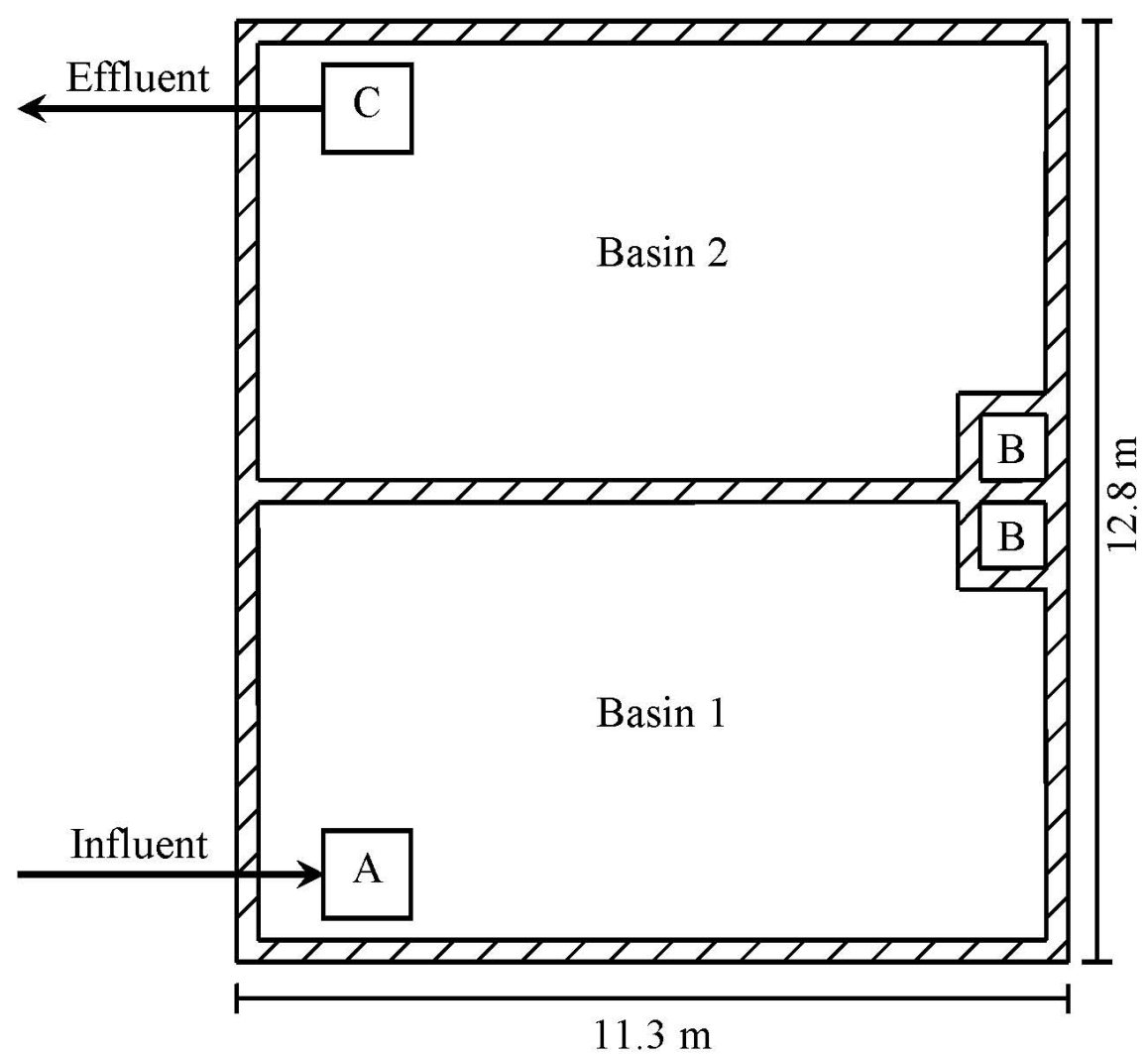

Figure 2b. Simplified plan view of the ReCip basins. (A) Influent standpipe location; (B) Sumps that housed the reciprocation pumps; (C) Effluent weir box that controlled the water level in Basin 2.

\subsection{Reciprocation schedule, influent flow, and precipitation}

Each of the two ReCip sumps housed a 0.5-HP high-flow, low-head propeller pump (Aquatic Eco-Systems, Apopka, Florida) that reciprocated water between the basins. A two-hour pumping schedule was repeated twelve times per day. A partial-day example is shown in Table 1. The pumping duration of 30 minutes was the time needed for drawdown of the water elevation from $91 \mathrm{~cm}$ to $15 \mathrm{~cm}$ (36 in to $6 \mathrm{in})$ within each basin. 
Table 1. Reciprocation pumping schedule, which was repeated every two hours.

\begin{tabular}{lllll}
\hline \multirow{2}{*}{ Pump Location } & \multicolumn{4}{l}{ Example Timing } \\
\cline { 2 - 5 } & 0800 & 0830 & 0900 & 0930 \\
\hline Basin 1 & On & Off & Off & Off \\
Basin 2 & Off & Off & On & Off \\
\hline
\end{tabular}

Pumping by the Basin 1 sump pump drained Basin 1 and filled Basin 2, discharging treated effluent over the effluent weir. The pumping schedule as well as high and low water elevations were constant throughout the study. Approximately $38 \mathrm{~m}^{3}$ $(10,000$ gal $)$ of water was contained in the basins based on the void space of the as-built rock layers, including the leach field chambers. Influent was loaded into Basin 1 for one hour, every four hours (totaling $8.7 \mathrm{~m}^{3} / \mathrm{d} ; 2,300 \mathrm{gal} / \mathrm{d}$ ). Based on the volume of water in the pores and the daily hydraulic loading rate, the theoretical hydraulic retention time (THRT) was determined to be 4.4 days. All residence times provided in this paper are based on pore volume.

Rainfall entering the ReCip basins diluted the wastewater being treated. Over the course of the 149 days of operation described herein, $42.2 \mathrm{~cm}$ of precipitation directly entered the ReCip. Daily precipitation was $>0.5 \mathrm{~cm} / \mathrm{d}$ (equivalent to $0.7 \mathrm{~m}^{3}$ or $8 \%$ of the daily influent flow) during 22 days (Table 2). 
Table 2. Dates of precipitation events $(>0.5 \mathrm{~cm} / \mathrm{d})$ during $149-\mathrm{d}$ period. Volume of rainfall entering basins, percent of influent flow during precipitation event, and affected sampling dates due to dilution caused by precipitation are shown.

\begin{tabular}{llcccl}
\hline Date(s) of event & $\begin{array}{c}\text { Precipitation } \\
(\mathrm{cm})\end{array}$ & $\begin{array}{c}\text { Volume } \\
\left(\mathrm{m}^{3}\right)\end{array}$ & $\begin{array}{c}\text { \% of influent } \\
\text { flow during event }\end{array}$ & $\begin{array}{l}\text { Sampling date(s) } \\
\text { affected }\end{array}$ \\
\hline 13 & Jan 2010 & 1.2 & 1.6 & $19 \%$ & 13 Jan 2010 \\
$17-22$ & Jan 2010 & 14.4 & 19.3 & $37 \%$ & 20, 27 Jan 2010 \\
26 & Jan 2010 & 1.5 & 2.0 & $23 \%$ & 27 Jan 2010 \\
$5-6$ & Feb 2010 & 4.1 & 5.5 & $32 \%$ & 10 Feb 2010 \\
9 & Feb 2010 & 1.4 & 1.9 & $22 \%$ & 10 Feb 2010 \\
24 & Feb 2010 & 1.3 & 1.7 & $20 \%$ & 24 Feb 2010 \\
$26-27$ & Feb 2010 & 5.4 & 7.2 & $42 \%$ & Sampling cancelled \\
$2-3$ & Mar 2010 & 2.6 & 3.5 & $20 \%$ & 10 Mar 2010 \\
6 & Mar 2010 & 0.6 & 0.8 & $9 \%$ & 10 Mar 2010 \\
$4-5$ & Apr 2010 & 2.5 & 3.4 & $19 \%$ & 7 Apr 2010 \\
$11-12$ & Apr 2010 & 2.7 & 3.6 & $21 \%$ & 15 Apr 2010 \\
20 & Apr 2010 & 1.3 & 1.7 & $20 \%$ & 22 Apr 2010 \\
\hline
\end{tabular}

Affected sampling dates are given because precipitation entering basins diluted the water sampled.

\subsection{Tracer study methods}

Two fluorescent dye tracer studies were performed to characterize the hydraulics of the pilot plant. Fluorometric analysis (Trilogy Laboratory Fluorometer, Turner Designs, Sunnyvale, California) using Rhodamine WT dye was selected with procedures adopted from the Techniques of Water-Resources Investigations of the United States Geological Survey (1986). Upon introduction of Rhodamine WT fluorescent dye into the pilot plant, sump (Basin 2) and effluent samples were taken every 20 minutes. Dye concentration was plotted against time for both the sump and effluent samples. Sump sampling concluded after sump dye concentrations were equivalent to effluent dye concentrations. Effluent sampling concluded after approximately two days, and an exponential decay curve was fitted to the effluent dye concentration data to predict the 
remaining effluent dye concentrations. Predictions were made because the remaining dye had not yet washed out of the system upon conclusion of sampling. The area under the extended curve of the actual and predicted effluent dye concentrations was integrated with respect to time, providing the estimated exiting mass of dye. The elapsed time for half of the dye to exit the system was calculated and represents the mean hydraulic residence time (MHRT).

The first study commenced on 28 September 2009 and concluded on 2 October 2009 , prior to any loading of lagoon water. In lieu of lagoon water, the pilot plant was filled to operational volume with tap water. Unlike the pulse loading of lagoon water, during the first tracer study, tap water was continually loaded into the pilot plant at a rate of $3.8 \mathrm{~L} / \mathrm{min}(1.0 \mathrm{gpm})$, resulting in a 7.0-d THRT. The reciprocation schedule was identical to that employed during the subsequent performance monitoring.

A second tracer study was performed from 23 June 2010 to 25 June 2010.

Although commencing after the completion of the 149-d time frame of the experiment, identical influent loading rates and reciprocation rates were employed during the second tracer study. Unlike the first tracer study, the pilot plant both contained and was loaded with lagoon water.

\subsection{Water quality analyses}

This paper reports influent and effluent water quality data from 13 January 2010 to 10 June 2010, referred to as the 149 -d period. Within a subset of that period, more detailed water quality analyses were conducted during a 9-week (65-d) period from 24 February 2010 to 29 April 2010. A nitrogen mass balance using sludge accumulation and 
composition was developed from this 65 -d period to indicate the fate of nitrogen entering the system. ReCip's potential for nitrogen and organic matter removal in dairy lagoon water was analyzed, with biological nitrification and denitrification studied as the primary treatment mechanisms. During the study, the HRT was held constant (4.4 days), as was the reciprocation schedule (Table 1). Influent water quality and weather were the uncontrolled variables (see Section 2.3 for precipitation data). Weekly water quality sampling and analysis was performed per Standard Methods (APHA, 2005). Influent grab samples were taken from the influent pipe directly before entering the system at 0900 on sampling days. Effluent grab samples were taken from water spilling over the effluent weir at 0855 on sampling days. Duplicates of influent and effluent were collected to ensure consistent grab sampling. Non-purgeable organic carbon (NPOC) and dissolved non-purgeable organic carbon (DNPOC) was analyzed using a Shimadzu TOCV CSH Total Organic Carbon Analyzer. The same analyzer was used in conjunction with the Shimadzu TNM-1 Total Nitrogen Measuring Unit to measure total nitrogen (TN) and dissolved nitrogen (DN). A large-bore sampling needle (800- $\mu \mathrm{m}$ inner diameter) was installed to accommodate larger particulates. However, any particles larger than the sampling needle would have been excluded. For DN, DNPOC, nitrite and nitrate analyses, filtered samples were prepared with $0.45-\mu \mathrm{m}$ Express Plus ${ }^{\circledR}$ membrane filters (Millipore, Billerica, Massachusetts). Then, filtered samples were preserved using concentrated sulfuric acid and stored, per APHA guidelines. A Dionex DX 120 ion chromatograph was used to measure nitrite and nitrate $\left(\mathrm{NO}_{2}{ }^{-}\right.$and $\left.\mathrm{NO}_{3}{ }^{-}\right)$. Due to the sample acidification, $\mathrm{NO}_{2}{ }^{-}$was oxidized to $\mathrm{NO}_{3}{ }^{-}$to some extent and, thus, oxidized nitrogen $\left(\mathrm{NO}_{2}^{-}+\mathrm{NO}_{3}{ }^{-}\right.$as $\left.\mathrm{N}\right)$ is reported. However, even in occasional fresh, unacidified 
samples, $\mathrm{NO}_{2}{ }^{-}$was $<2.5 \mathrm{mg} / \mathrm{L}$. During both NPOC/TN and $\mathrm{NO}_{2}{ }^{-}+\mathrm{NO}_{3}{ }^{-}$analysis, sample blanks, matrix spikes, duplicates, and splits were performed within each sample batch to assure and control quality. Additionally, a spinach leaf standard reference (SRM 1570a, National Institute of Standards and Technology) was analyzed by the NPOC/TN analyzer to further assure data quality.

\subsection{Sludge monitoring and analysis}

Sludge accumulation on the floor of the ReCip pilot plant basins was monitored monthly through the standpipes that passed through openings in the top of the chambers and protruded above the rock surface. For consistent and reproducible monitoring of the sludge layer thickness, a peristaltic pump with a flow rate of approximately $500 \mathrm{~mL} / \mathrm{min}$ with 1.0-cm diameter vinyl tubing was used for sampling. The vinyl intake tubing was attached to a rigid pipe calibrated with length markings (1-cm intervals) and lowered into each standpipe at a rate of $1 \mathrm{~cm} / \mathrm{sec}$. Upon the appearance of dark sludge particles in the intake tube, the depth to the sludge was recorded and subtracted from the known depth to the bottom of the tank to determine the sludge thickness in the 15 standpipes of each basin. See Section 2.2 for description of standpipe locations. During sampling, sludge was collected from the entire thickness of the sludge layer to provide an accurate representation of the total solids and elemental composition. The mean sludge thickness in each basin was determined by averaging the calculated depths in the 15 standpipes. Sludge volumes were calculated based on the dimensions of each basin, ignoring the sumps. Sludge accumulated in the rock pores was not measured. Samples were analyzed for total solids (TS) and volatile solids (VS). Additionally, the Dumas combustion method (Vario MAX CNS Macro Elemental Analyzer, Elementar Americas Inc., Mt. 
Laurel, New Jersey) was used to analyze samples for total carbon (TC) and total nitrogen (TN). A tomato leaf standard reference (SRM 1573a, National Institute of Standards and Technology) was tested with each batch of samples along with blanks and splits for quality assurance and control. Sludge volumes were multiplied by the total solids and elemental percentages to determine the mass of solids, nitrogen, and carbon in the sludge layer of each basin.

\subsection{Air quality monitoring}

Preliminary air emissions measurements were performed near the conclusion of the 149-d experiment on 5 June 2010 to 7 June 2010 by Dr. Yongjing Zhao of Dr. Frank Mitloehner's group at the University of California, Davis. Flux chambers buried 30-cm into the rock layer collected gas emitted from the pilot plant over the course of a complete two-hour pumping cycle. The flux chambers were 20 -L plastic pails with their bottoms cut away. The pails were sealed with air-tight lids with gas transfer tubing attached with stainless steel tank adapter fittings. Three analyzers connected to the flux chambers measured various gases. An INNOVA Multi-gas Analyzer (LumaSense Technologies Inc., Santa Clara, California) measured ammonia $\left(\mathrm{NH}_{3}\right)$, nitrous oxide $\left(\mathrm{N}_{2} \mathrm{O}\right)$, carbon dioxide $\left(\mathrm{CO}_{2}\right)$, methanol, and ethanol. A hydrogen sulfide $\left(\mathrm{H}_{2} \mathrm{~S}\right)$ and sulfur dioxide $\left(\mathrm{SO}_{2}\right)$ analyzer (Model 450i, Thermo Fisher Scientific, Waltham, Massachusetts) and a direct methane $\left(\mathrm{CH}_{4}\right)$ and non-methane hydrocarbon analyzer (Model 55c, Thermo Fisher Scientific, Waltham, Massachusetts) were also used. Additionally, the previously mentioned analyzers were used to measure gas volatilization from influent and effluent samples stored in 20-L plastic pails with lids fitted with gas 
flushing and sample collection tubing. This gas sampling was conducted over the course of two hours.

\subsection{Regression model development}

Linear and nonlinear models of ammonium removal were prepared and analyzed for best fit to the data. SigmaPlot ${ }^{\circledR}$ software (Version 11, Systat Software Inc., San Jose, California) was used to fit model parameters to model equations using least-squares routines. The variables deemed most significant for use in the models were influent TAN, theoretical hydraulic residence time (THRT), and effluent temperature. Effluent temperatures were incorporated into an Arrhenius-type adjustment factor and were only included in the nonlinear models. The linear model formulated to describe TAN removal was as follows:

$$
\Delta \mathrm{N} / \theta=\alpha \mathrm{N}+\beta
$$

where

$$
\begin{aligned}
& \Delta \mathrm{N} / \theta=\text { TAN removal rate based on theoretical hydraulic residence time }(\mathrm{mg} / \mathrm{L}-\mathrm{d}) \\
& \mathrm{N}=\text { Influent TAN concentration }(\mathrm{mg} / \mathrm{L}) \\
& \alpha, \beta=\text { Fitting parameters }
\end{aligned}
$$

TAN concentrations in the effluent did not decrease to levels thought to be limiting to nitrification based on typical ammonium half-saturation constants of $0.1-5.0 \mathrm{mg} / \mathrm{L}$ $\mathrm{NH}_{4}{ }^{+}-\mathrm{N}\left(15-25^{\circ} \mathrm{C}\right)$ (Halling-Sørensen and Jørgensen, 1993). Thus, dissolved oxygen was more likely to be the substance that limited nitrifier growth rate. Nonetheless, the TAN removal rate was assumed to be first-order with respect to TAN, hence a 
concentration parameter, $\alpha$, was used. The intercept parameter, $\beta$, accounts for any zeroorder TAN removal mechanisms. For model testing, four nonlinear models were formulated to describe TAN removal, as follows:

$$
\begin{aligned}
& \Delta \mathrm{N} / \theta=[\alpha \mathrm{N}+\beta] \mathrm{x} \mathrm{k}_{\mathrm{T}}^{\mathrm{T}-20} \quad \text { and } \quad \Delta \mathrm{N} / \theta=[\alpha \mathrm{N}+\beta] \mathrm{x} \mathrm{k}_{\mathrm{T}}^{\mathrm{T}-16.3} \quad(\text { Eqs. } 2 \& 3)
\end{aligned}
$$

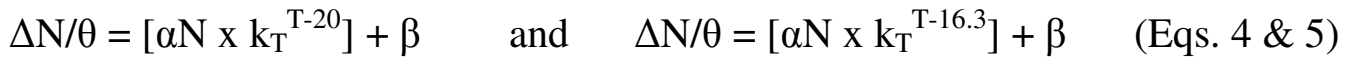

where

$\mathrm{k}_{\mathrm{T}}=$ Arrhenius-like temperature adjustment factor

$\mathrm{T}=$ Effluent temperature $\left({ }^{\circ} \mathrm{C}\right)$

The differences among the equations are the value of the constant in the temperature adjustment and whether $\beta$ received the temperature adjustment. Equations 3 and 5 use 16.3 instead of 20 in the Arrhenius-type adjustment exponent because $16.3^{\circ} \mathrm{C}$ is the mean temperature in the data set, which centers the model. Models were judged for their ability to describe as well as predict the data set. For description testing, calculated TAN removal rates provided by each model were plotted against measured TAN removal rates. For prediction testing, best-fit model parameters were determined using only the first half of the 149-d data set (13 January 2010 to 24 March 2010). The models, with the best-fit parameters, were then used to predict TAN removal during the second half of the data set (31 March 2010 to 10 June 2010). The predicted second half of the data set was then plotted against the measured second half of the data set to assess the accuracy of the predictions. 


\section{Results and Discussion}

\subsection{TAN removal during 149 -d period}

Average influent and effluent water quality results and removal efficiencies from the entire 149-d sampling period (13 January 2010 to 10 June 2010) are displayed in Table 3.

Table 3. Influent and effluent water quality results from weekly grab samples during the 149-d experiment (mean $+/$ - standard deviation; $n=20$ ).

\begin{tabular}{llllllc}
\hline & \multicolumn{3}{c}{ Influent } & \multicolumn{3}{c}{ Effluent } \\
\hline & Units & Mean & $+/-$ & Mean & $+/-$ & \% Removal \\
\hline Temperature & ${ }^{\circ} \mathrm{C}$ & 16.7 & 3.15 & 16.3 & 2.49 & - \\
Dissolved Oxygen & $\mathrm{mg} / \mathrm{L}$ & 0.2 & 0.17 & 1.4 & 0.68 & - \\
$\mathrm{pH}$ & - & 7.5 & 0.10 & 8.1 & 0.12 & - \\
Total SS & $\mathrm{mg} / \mathrm{L}$ & 1,408 & 163.0 & 591 & 131.9 & $58 \%$ \\
Volatile SS & $\mathrm{mg} / \mathrm{L}$ & 1,150 & 127.2 & 467 & 101.5 & $59 \%$ \\
Total Ammoniacal N & $\mathrm{mg} \mathrm{N} / \mathrm{L}$ & 221 & 31.5 & 15 & 7.0 & $93 \%$ \\
NPOC & $\mathrm{mg} \mathrm{C} / \mathrm{L}$ & 673 & 97.2 & 213 & 56.5 & $68 \%$ \\
Total BOD & $\mathrm{mg} / \mathrm{L}$ & 370 & 63.2 & 192 & 45.5 & $48 \%$ \\
\hline
\end{tabular}

Notation: SS is suspended solids; NPOC is non-purgeable organic carbon; $\mathrm{BOD}_{5}$ is fiveday biochemical oxygen demand.

Total and volatile suspended solids were similarly removed. Although some settling occurred on the basin floors, particulate solids likely decomposed into soluble products on the surface of the biofilm (Halling-Sørensen and Jørgensen, 1993). Carbon was well removed, as indicted by the removal of NPOC. The most significant result of the 149period was the high removal percentage of TAN (93\%) while influent TAN concentrations averaged over $200 \mathrm{mg} \mathrm{N} / \mathrm{L}$. TAN removal through biological nitrification requires the presence of adequate dissolved oxygen (DO). Dissolved oxygen was consistently elevated in effluent samples in comparison to the anoxic lagoon water influent, as indicated by the average influent and effluent DO concentrations in Table 3. 
Increased DO in the biofilms promotes nitrification and TAN removal and is a direct result of the novel reciprocation process (Leonard et al., 2003).

\subsection{Detailed water quality analyses and nitrogen removal during 65-d period}

More comprehensive water quality testing was performed from 24 February 2010 to 29 April 2010 (65-d period) compared to the full 149-d period (Table 3) to analyze concentration changes in nitrogen species and provide a nitrogen balance over the $65-\mathrm{d}$ period (Table 4).

Table 4. Influent and effluent water quality results from weekly grab samples during the 65-d experiment (mean +/- standard deviation; $\mathbf{n}=9$ ).

\begin{tabular}{llllllc}
\hline & & Influent & \multicolumn{5}{c}{ Effluent } \\
\hline & Units & Mean & + +- & Mean & $+/-$ & \% Removal \\
\hline Temperature & ${ }^{\circ} \mathrm{C}$ & 16.6 & 1.57 & 16.1 & 1.42 & - \\
$\mathrm{pH}$ & - & 7.5 & 0.06 & 8.0 & 0.10 & - \\
Dissolved Oxygen & $\mathrm{mg} / \mathrm{L}$ & 0.3 & 0.19 & 1.8 & 0.80 & - \\
Total SS & $\mathrm{mg} / \mathrm{L}$ & 1,349 & 79.5 & 533 & 64.0 & $61 \%$ \\
Carbonaceous BOD & $\mathrm{mg} / \mathrm{L}$ & 261 & 52.6 & 115 & 29.9 & $56 \%$ \\
NPOC & $\mathrm{mg} \mathrm{C} / \mathrm{L}$ & 634 & 67.9 & 196 & 69.2 & $69 \%$ \\
Dissolved NPOC & $\mathrm{mg} \mathrm{C} / \mathrm{L}$ & 238 & 21.1 & 151 & 21.9 & $37 \%$ \\
Total Alkalinity & $\mathrm{mg} \mathrm{CaCO} / \mathrm{L}$ & 2,611 & 754 & 1178 & 494 & $55 \%$ \\
Total N & $\mathrm{mg} / \mathrm{L}$ & 316 & 21.2 & 160 & 14.4 & $49 \%$ \\
Dissolved N & $\mathrm{mg} / \mathrm{L}$ & 213 & 16.8 & 144 & 9.9 & $32 \%$ \\
Total Ammoniacal N & $\mathrm{mg} \mathrm{N} / \mathrm{L}$ & 214 & 18.8 & 13 & 8.5 & $94 \%$ \\
$\mathrm{NO}_{3}{ }^{-}$ & $\mathrm{mg} \mathrm{N} / \mathrm{L}$ & 0.2 & 0.07 & 88 & 22.4 & - \\
$\mathrm{NO}_{2}{ }^{-}$ & $\mathrm{mg} \mathrm{N} / \mathrm{L}$ & $<0.1$ & - & 1.2 & 0.47 & - \\
\hline
\end{tabular}

Removal of nitrogenous and carbonaceous constituents is evident in all parameters except $\mathrm{NO}_{3}{ }^{-}$and $\mathrm{NO}_{2}{ }^{-}$, which show significant increases in concentration (Table 4). Dissolved carbon (as dissolved NPOC) remains prevalent, suggesting carbon 
is not limiting as an electron donor for denitrification assuming it is biologically available.

The consumption of alkalinity and sensitivity to $\mathrm{pH}$ inherent to nitrification provided concern prior to pilot plant operation (Spierling et al., 2009). During the 65-d period, an average of $7.0 \mathrm{mg}$ alkalinity was destroyed per $\mathrm{mg}$ TAN removed. However, effluent alkalinity levels and significant TAN removal suggest no alkalinity supplementation (e.g., caustic soda) would need to be added to the influent to allow nearly complete TAN removal.

Total nitrogen (TN) was assumed to be composed of TAN, $\mathrm{NO}_{3}^{-}$, and organic nitrogen $(\mathrm{ON})$. Although $\mathrm{ON}$ was not directly measured, it was calculated as the remainder of TN after TAN and $\mathrm{NO}_{3}{ }^{-}$were subtracted. An insignificant amount of $\mathrm{NO}_{2}{ }^{-}$ $(1.2 \mathrm{mg} / \mathrm{L})$ was measured in the effluent and therefore omitted from total nitrogen composition analysis and mass balance. The composition of TN in the influent and effluent, based on the three assumed constituents, was analyzed (Figures 3a, 3b). 


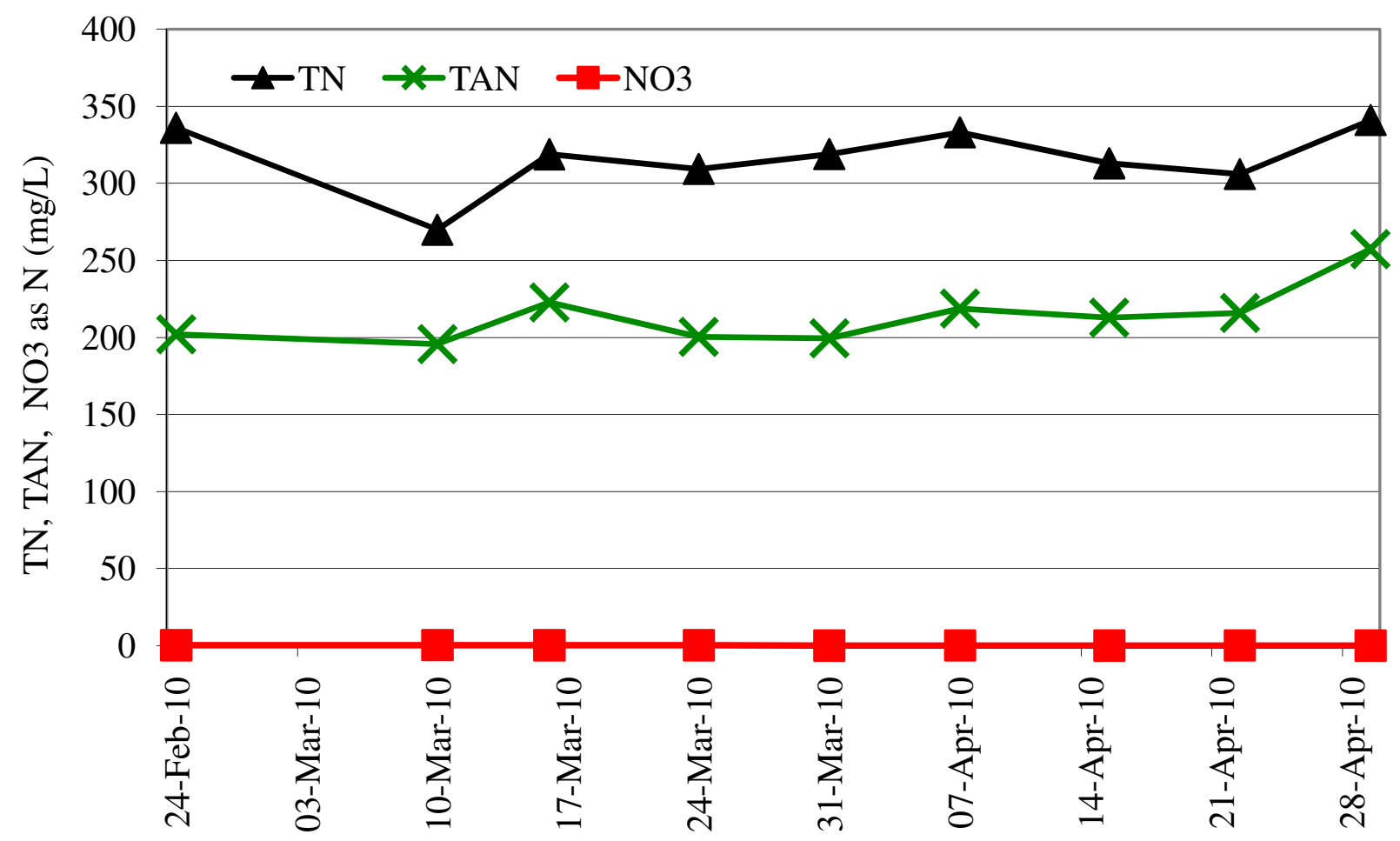

Figure 3a (above). Influent nitrogen composition from 24 Feb 2010 to 29 Apr 2010.

Figure 3b (below). Effluent nitrogen composition from 24 Feb 2010 to 29 Apr 2010.

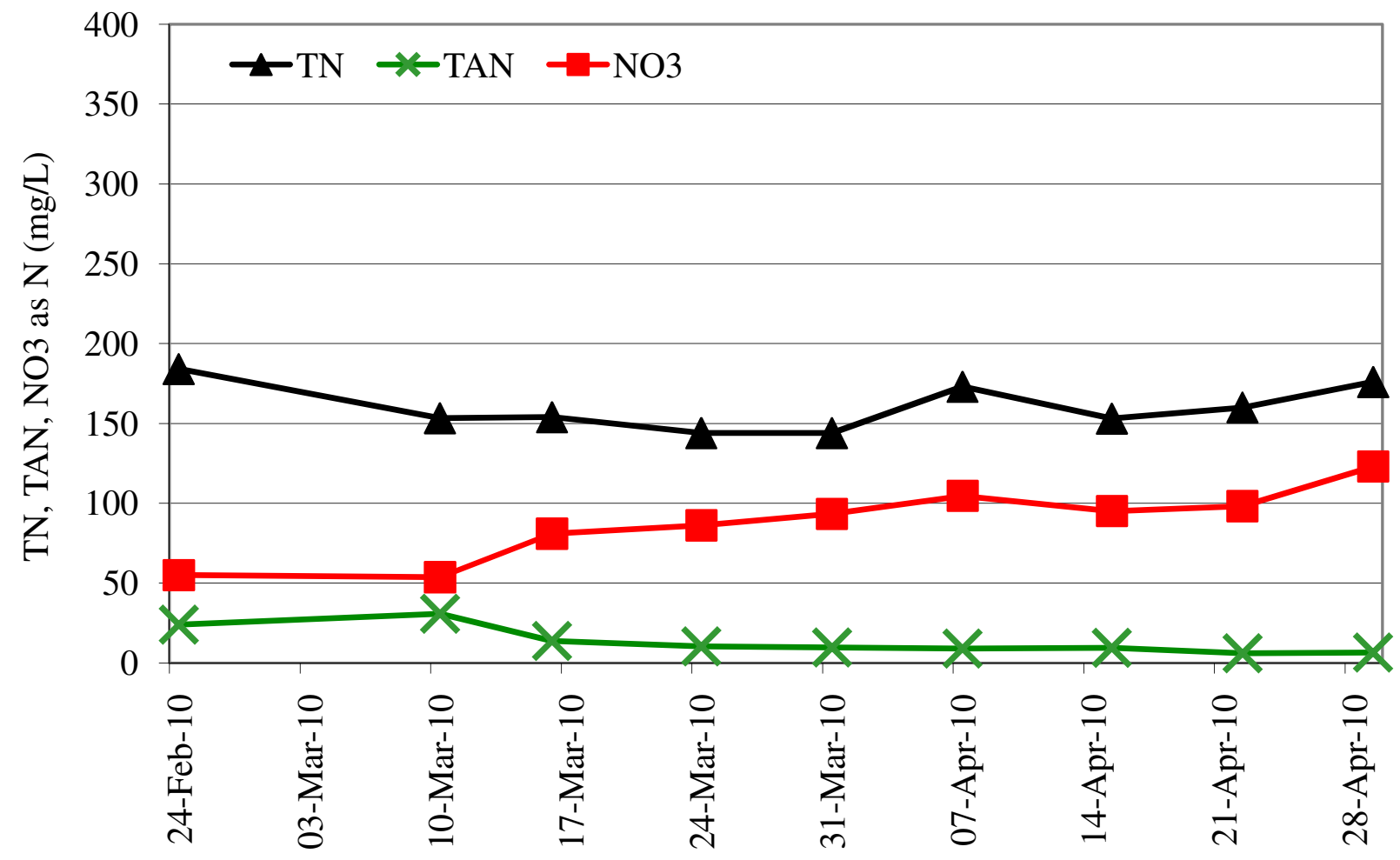


Before conclusions could be made on nitrification and denitrification, sludge accumulation and analysis was performed to determine how much total nitrogen was removed by settling (Section 3.5).

\subsection{Tracer Study Results}

In order to evaluate hydraulic performance of the pilot plant, the theoretical hydraulic residence time (THRT) was compared with the mean hydraulic residence time (MHRT) as determined in two tracer studies. Peak effluent dye concentrations in both studies were observed approximately three hours after the introduction of dye, followed by a gradual decrease of concentration as the dye was flushed out of the pilot plant. Figures B.1 and B.2 in the Appendices provide plots of effluent Rhodamine concentrations-versus-time. The first tracer study was performed during constant 3.8 L/min loading of tap water, giving a 7.0-d THRT, and determined the MHRT to be 2.9 days. It is estimated that $55 \%$ of the fluorescent dye was attenuated in the pilot plant, presumably adhering to the rock substrate and/or due to the conclusion of sampling before the decay curve reached the asymptote. The second tracer study, performed under conditions identical to those of the 149-day experiment (4.4-d THRT), revealed the MHRT to be 1.8 days. Only $26 \%$ of the injected dye mass was estimated to have exited the pilot plant during the sampling of the second tracer study. The dye retained in the pilot plant is assumed to have been absorbed by organic matter or was unaccounted for due to the short sampling period. The MHRT-to-THRT ratio of both tracer studies was 0.42-to-1 despite the differences in flow and loading schedule (continuous vs. pulsed). Sampling in the intermediate sump revealed large oscillations in dye concentration due to the reciprocation pumping. The early, sudden peak and ensuing gradual decay of dye 
concentration in both studies revealed that the pilot plant hydraulics were similar to a continuous-flow stirred tank reactor (CSTR), but with substantial short-circuiting indicated by the high MHRT-to-THRT ratios.

\subsection{TAN removal model selection}

For each model shown in Table 5, the coefficient of determination $\left(\mathrm{R}^{2}\right)$ of each calculated-versus-observed correlation was first used to determine the best descriptive model (equations listed in Section 2.8).

Table 5. Coefficient of determinants $\left(\mathbf{R}^{2}\right)$, fitting parameters $(\alpha, \beta)$, and Arrheniustype adjustment factors of TAN removal models for the 149-d period. $R^{2}$ values from calculated-versus-observed correlation. $P$-values for each equation are corrected for mean of observations.

\begin{tabular}{lllllll}
\hline Eqn & Model & $\mathrm{R}^{2}$ & P-value & $\alpha$ & $\beta$ & $\mathrm{k}_{\mathrm{T}}$ \\
\hline 1 & $\Delta \mathrm{N} / \theta=\alpha \mathrm{N}+\beta$ & 0.90 & $<0.001$ & 0.237 & -4.818 & - \\
2 & $\Delta \mathrm{N} / \theta=[\alpha \mathrm{N}+\beta] \mathrm{x} \mathrm{k}_{\mathrm{T}}^{\mathrm{T}-20}$ & 0.90 & $<0.0001$ & 0.246 & -7.341 & 0.996 \\
3 & $\Delta \mathrm{N} / \theta=[\alpha \mathrm{N}+\beta] \mathrm{x} \mathrm{k}_{\mathrm{T}}^{\mathrm{T}-16.3}$ & 0.90 & $<0.0001$ & 0.250 & -7.451 & 0.996 \\
4 & $\Delta \mathrm{N} / \theta=\left[\alpha \mathrm{N} \times \mathrm{k}_{\mathrm{T}}^{\mathrm{T}-20}\right]+\beta$ & 0.30 & 0.046 & -0.008 & 54.591 & 0.729 \\
5 & $\Delta \mathrm{N} / \theta=\left[\alpha \mathrm{N} \mathrm{x} \mathrm{k_{ \textrm {T } } ^ { \mathrm { T } }}{ }^{-16.3}\right]+\beta$ & 0.90 & $<0.0001$ & 0.249 & -7.358 & 0.997 \\
\hline
\end{tabular}

Notation: $\Delta \mathrm{N}$ is change in TAN concentration between influent and effluent; $\theta$ is theoretical hydraulic residence time; $\alpha$ and $\beta$ are first and zero order fitting parameters, respectively; $\mathrm{k}_{\mathrm{T}}$ is Arrhenius-like temperature adjustment factor.

Excluding Equation 4, the best-fit parameters for the nonlinear (temperature dependent) models were nearly identical, as well as the $\mathrm{R}^{2}$ values for the calculated-versus-observed correlations. The linear (not temperature dependent) model produced only a different $\beta$ value.

For prediction testing, the best-fit parameters were determined from only the first half of the data set (13 January 2010 to 24 March 2010). These calibrated models were used to predict the TAN removal rate during the second half of the data set (31 March 
2010 to 10 June 2010). In general, the TAN removal rates of the second half of the data set were higher than the first half of the data set. Much like the descriptive comparison, the predictive capabilities of Equations 2, 3, and 5 were similar. The $\mathrm{R}^{2}$ correlation value of the linear Equation 1 predictions (Figure 4) was 0.93, compared to 0.90 for the nonlinear models predictions.

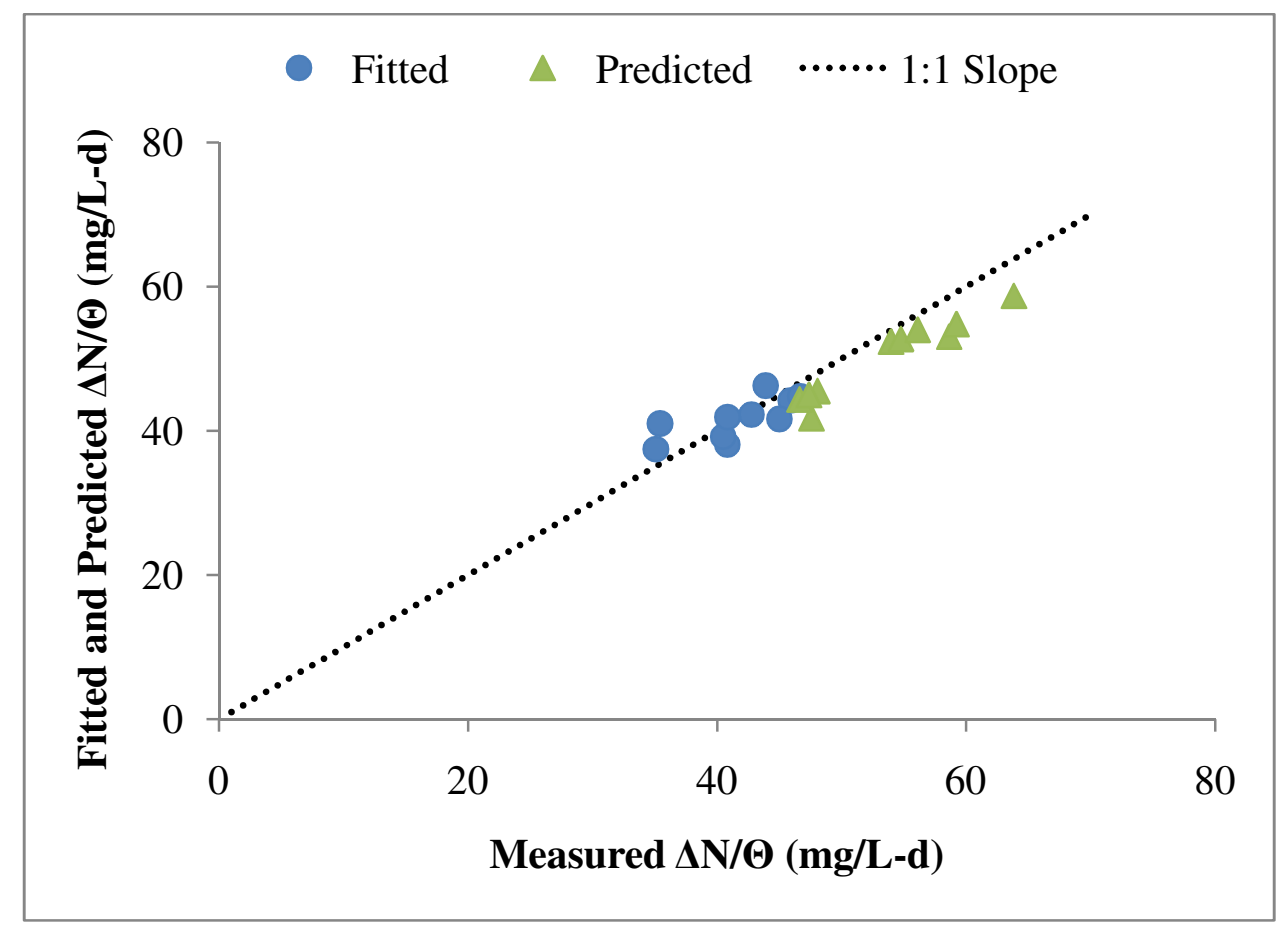

Figure 4. Fitted and predicted periods using the linear TAN removal model (Eq. 1). The best-fit model parameters were determined using first half of data set, with fitted-versus-measured correlation plotted. The calibrated model and influent TAN concentrations from the second half of the data set were used to predict TAN removal rates.

The predicted period trendlines of the predictive linear and nonlinear models had intercepts greater than zero yet predicted TAN removal rates that were lower than measured, indicating that the predictive capability of each model is influenced by TAN removal rate. In comparison to the nonlinear models, the predicted period trendline intercept of the linear model was closer to zero signifying the linear model is less affected 
by variations in TAN removal rates. As a result, Equation 1 (linear model) is the best model to represent the Cal Poly ReCip. However, a temperature dependent model may be useful in the future for sites with greater seasonal temperature variation because of the temperature dependency of nitrification (Halling-Sørensen and Jørgensen, 1993), and in turn TAN removal. The Cal Poly, San Luis Obispo temperature data does not range widely and leads to a near-unity, negative value of $\mathrm{k}_{\mathrm{T}}$ for all nonlinear models.

Contrasting to Equation 2 and 3, Equation 5 does not correct the intercept $(\beta)$ with temperature and therefore seems more likely to accurately account for temperature dependent nitrification by only adjusting the first order influent TAN concentration parameter $(\alpha)$. Equation 5 is then selected as the model most likely to be useful in regions with greater seasonal temperature variations than San Luis Obispo. Entering the previously listed parameters determined through regression, Equation 5 becomes:

$$
\Delta \mathrm{N} / \theta=\left[0.249 \mathrm{~N} \times 0.997^{\mathrm{T}-16.3}\right]-7.358
$$

Although temperature was not important in this study due to the minor observed seasonal variation in temperature, it is likely to be a significant factor upon additional data collection and operation in locations with more extreme temperature variations. Additionally, Equation 5 uses the mean temperature in the Arrhenius-type adjustment factor, differing from Equation 4 which uses $20^{\circ} \mathrm{C}$.

\subsection{Sludge accumulation and analysis}

Sludge accumulation in each basin is the byproduct of settled solids and biofilm sloughing. Monthly monitoring was performed on four dates over the course of the 149$\mathrm{d}$ experiment and an additional date after the end of the period (Table 6). 
Table 6. Sludge accumulation monitoring data. Based on average sludge depths of 15 standpipes.

\begin{tabular}{lllll}
\hline \multirow{2}{*}{ Date } & \multicolumn{2}{c}{ Basin 1 } & \multicolumn{3}{c}{ Basin 2 } \\
\cline { 2 - 5 } & Depth & Volume & Depth & Volume \\
\cline { 2 - 5 } & $(\mathrm{cm})$ & $\left(\mathrm{m}^{3}\right)$ & $(\mathrm{cm})$ & $\left(\mathrm{m}^{3}\right)$ \\
\hline 22-Feb-2010 & 8.4 & 5.62 & 1.8 & 1.20 \\
10-Mar-2010 & 4.5 & 3.01 & 1.7 & 1.14 \\
8-Apr-2010 & 5.3 & 3.55 & 1.9 & 1.27 \\
6-May-2010 & 9.1 & 6.09 & 3.0 & 2.01 \\
7-Jul-2010 & 10.0 & 6.69 & 3.0 & 2.01 \\
\hline
\end{tabular}

Excluding the first sludge sampling date, each basin showed an increase in sludge depth during the course of the experiment. In the Basin 1, sludge levels were higher nearest the influent pipe and along the walls furthest away from the sump. Basin 2 sludge was highest close to the sump and decreased spatially closer to the effluent weir (refer to Figure $2 \mathrm{~b}$ for plan view of basins). In conjunction with sludge height monitoring, sludge was sampled from the standpipes nearest the influent pipe and effluent weir. Samples were analyzed for total solids (TS) and volatile solids (VS) as well as carbon and nitrogen percentage (Table 7). Average sludge volume was calculated from average thickness of the sludge layer accumulated on the basin floors.

Table 7. Average sludge levels and composition (\% $\mathrm{N}$ and $\% \mathrm{C}$ of $\mathrm{TS})$ in each basin during 149-d experiment.

\begin{tabular}{lllllll}
\hline Location & $\begin{array}{l}\text { Depth } \\
(\mathrm{cm})\end{array}$ & $\begin{array}{l}\text { Volume } \\
\left(\mathrm{m}^{3}\right)\end{array}$ & $\begin{array}{l}\mathrm{TS} \\
(\mathrm{g} / \mathrm{L})\end{array}$ & $\begin{array}{l}\mathrm{VS} \\
(\mathrm{g} / \mathrm{L})\end{array}$ & $\% \mathrm{~N}$ & $\% \mathrm{C}$ \\
\hline Basin 1 & 6.8 & 4.57 & 39.4 & 22.7 & 2.8 & 28.0 \\
Basin 2 & 2.1 & 1.40 & 42.0 & 20.2 & 3.3 & 21.3 \\
\hline
\end{tabular}

The actions of sludge layer consolidation and anaerobic degradation (Nelson et al., 2004) are expected to lead to a declining rate of sludge accumulation over time. At 
some point, it is expected that sludge removal via the basin ports will be required in order to maintain the porosity and function of the aggregate beds.

\subsection{Nitrogen mass balance}

A nitrogen mass balance (Figure 5) was conducted using influent and effluent water quality data from the detailed 65-d analysis (24 February 2010 to 29 April 2010)

and nitrogen in the accumulated sludge (Table 7). Influent and effluent $\mathrm{TAN}, \mathrm{NO}_{3}^{-}$, and ON concentrations comprised the nitrogen entering and leaving the pilot plant in the water column.

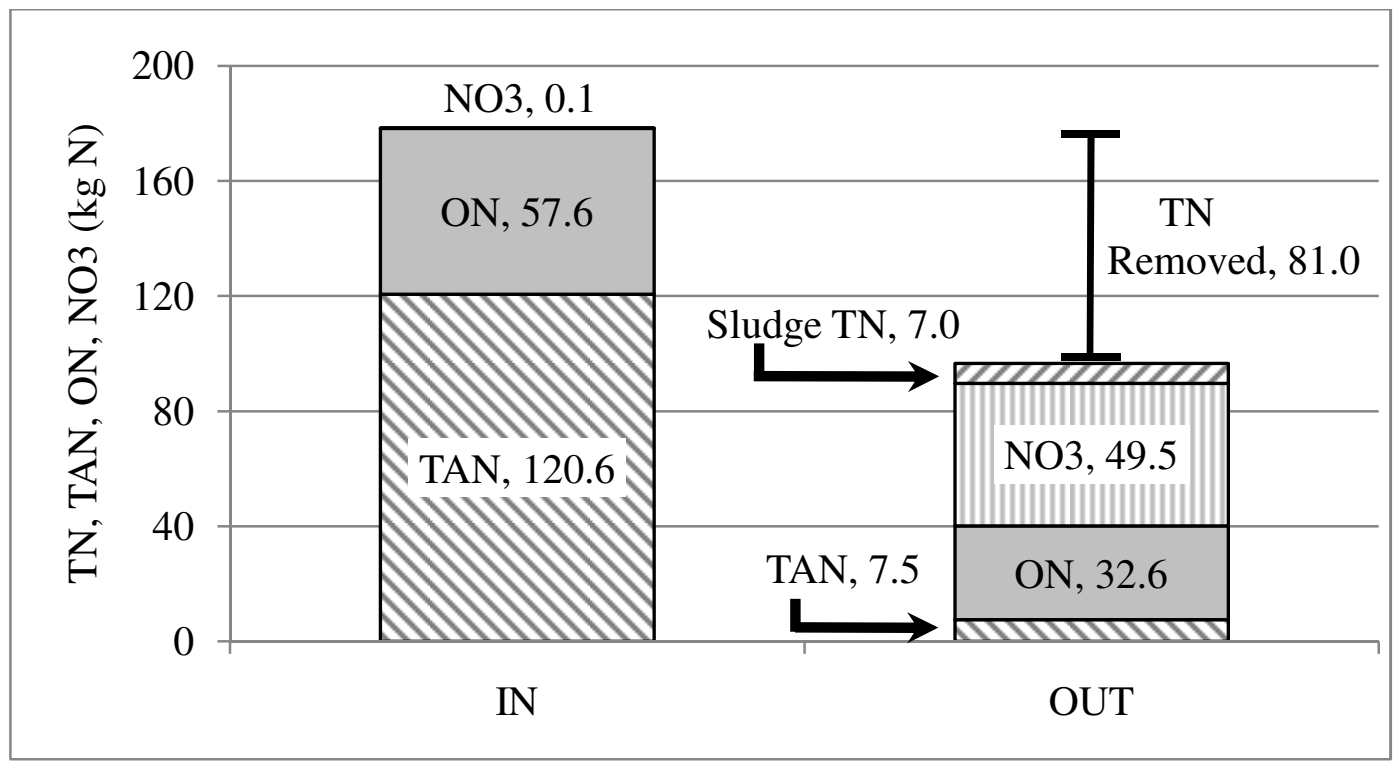

Figure 5. Nitrogen mass balance based on the detailed water quality analyses during 24 February 2010 to 29 April 2010. TN removed, shown as difference between IN and OUT, is presumed to have been released as $\mathrm{N}_{2} \mathrm{O}$ and/or $\mathrm{N}_{2}$ gas. The $\mathrm{NO}_{3}{ }^{-}$discharged with the effluent to the anaerobic lagoon was presumably denitrified in the anoxic lagoon.

$\mathrm{NO}_{2}^{-}$was not included in the mass balance due to a negligible influent concentration and minor effluent concentration in comparison to $\mathrm{NO}_{3}{ }^{-}$. Sludge $\mathrm{TN}$ is included under mass out to account for nitrogen settled in the system as biomass or as nonvolatile solids. 
Nitrogen unaccounted for in the effluent water and settled sludge is assumed to have left the system primarily as $\mathrm{N}_{2}$ gas.

\subsection{Preliminary air quality results}

Preliminary air emissions measurements were performed from 5 June 2010 to 7 June 2010 at five locations in the pilot plant using flux chambers. Results averaged between three sampling spots near the influent, sump, and effluent locations,

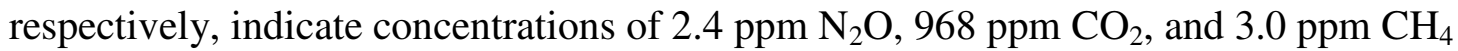
during the draining and ensuing rest stages of the reciprocation pumping cycle. During reciprocation biofilms were exposed to air, transferring these metabolic gases from the liquid film to the bulk air of the pore spaces of the ReCip aggregate beds. Biological nitrogen removal processes release $\mathrm{N}_{2} \mathrm{O}$ during both aerobic and anoxic phases (Ahn et al., 2010). Comparison of the emission rates from influent and effluent samples indicated significantly lower emission rates for $\mathrm{NH}_{3}, \mathrm{H}_{2} \mathrm{~S}$, and $\mathrm{CH}_{4}$ in the effluent sample. Additional air emissions measurements will be conducted at the Cal Poly ReCip site in the near future.

\subsection{Comparison of results to previous studies}

Water constituent removal by the Cal Poly dairy ReCip pilot plant was compared with two other ReCip systems installed at swine farms (Table 8) because of the similar expected values for influent lagoon water constituents (NRCS, 1992). Water in both swine lagoons was pretreated with solids removal systems incorporating solids screens, similar to the Cal Poly dairy. 
Table 8. Percent removal of selected constituents of three ReCip systems. For the Cal Poly dairy results are from 24 February 2010 to 29 April 2010.

\begin{tabular}{llllll}
\hline \multirow{2}{*}{ ReCip System } & Flow & HRT & \multicolumn{3}{l}{ Percent Removal } \\
\cline { 5 - 7 } & $\left(\mathrm{m}^{3} / \mathrm{d}\right)$ & $(\mathrm{d})$ & CBOD $_{5}$ & TAN & TSS \\
\hline Dairy farm, Cal Poly & 8.7 & 4.4 & $56 \%$ & $94 \%$ & $61 \%$ \\
Swine farm, AL (Behrends et al., 2004) & 208 & 4.5 & $77 \%$ & $91 \%$ & - \\
Swine farm, NC (Rice and Humenik, 2004) & 76 & 6.0 & - & $57 \%$ & $95 \%$ \\
\hline
\end{tabular}

The Cal Poly pilot plant achieved the greatest TAN removal efficiency of the three comparable systems, but also had the lowest TAN influent concentration. Because ReCip is primarily a nitrification/denitrification system, the production of $\mathrm{NO}_{3}{ }^{-}$is prevalent with the oxidation of TAN. The two swine systems showed dramatic increases in $\mathrm{NO}_{3}{ }^{-}$ production (Behrends et al., 2004; Rice and Humenik, 2004) as was observed in the current study with dairy lagoon water. Temperature data could not be compared to either swine study because it was not provided in the literature. Cycle timing was not mentioned by Behrends et al. (2004), although the Rice and Humenik (2004) study employed 10 daily cycles every $1.5 \mathrm{hr}$, with a 9-hr nighttime rest period when water levels in each basin equilibrated. Additionally, the North Carolina ReCip system (Behrends et al., 2004) had four basins operated in series, while the Alabama ReCip system had two basins in series (Rice and Humenik, 2004). During the 65-d period from 24 February 2010 to 29 April 2010 at the Cal Poly ReCip, $178 \mathrm{~kg} \mathrm{~N}$ and $90 \mathrm{~kg}$ N entered and exited the pilot plant, respectively. $7.0 \mathrm{~kg} \mathrm{~N}$ was found to have been retained in the system as sludge through sludge monitoring and compositional analysis. Based on the mass of the total nitrogen removed, the plan area of both basins, and the 65-d period of the nitrogen mass balance, $0.01 \mathrm{~kg} \mathrm{~N} / \mathrm{m}^{2}-\mathrm{d}$ was removed from the influent flow. 


\section{Conclusions}

$\mathrm{CBOD}_{5}$ and $\mathrm{N}$ removal were characterized for a ReCip pilot plant operating with a 30-min:30-min reciprocation pattern and loadings of $2.7 \mathrm{~kg} \mathrm{~N} / \mathrm{d}$ and $2.3 \mathrm{~kg} \mathrm{CBOD} 5 / \mathrm{d}$. Under these conditions, nitrification of ammonium was nearly complete, but denitrification was incomplete. Preliminary air emissions results comparing the influent lagoon water to the treated ReCip effluent suggest a decrease in the potential emissions of ammonia, hydrogen sulfide, and methane.

Similar to other biological wastewater treatment systems, the significant removal mechanism was the conversion of nitrogen and organic matter into metabolic gases by biofilms growing on rock substrate. Dissolved oxygen supplied to the biofilms through reciprocation led to strong TAN removal through nitrification. Total nitrogen removal was documented, presumably through denitrification during the anoxic period of each reciprocation cycle. Under the reciprocation pattern studied, nitrification was extensive, as indicated by the high average nitrate concentration in the effluent ( $88 \mathrm{mg} \mathrm{N} / \mathrm{L})$. If longer rest periods during the reciprocation pattern are implemented to promote longer anoxic periods, the relative amounts of nitrate denitrified might be increased. A less significant treatment mechanism was solids settling, as documented by the sludge accumulation rate in both basins. Over time, consolidation and degradation of solids is expected to lead to declining accumulation rates, but the accumulation of sludge may impact treatment performance.

The current study indicates that the ReCip technology is suitable for treatment of dairy lagoon wastewater and that ReCip may be useful for flush dairies that have 
difficulty maintaining a whole-farm nutrient balance due to insufficient cropland for manure application at agronomic rates.

\subsection{Future research}

In the future, operational adjustments utilizing different hydraulic residence times, influent loading rates, and/or reciprocation cycles should be explored for increasing nitrate removal. The current operational setup discharges nitrate-rich water back into the same storage lagoon that provides the influent, presumably denitrifying the nitrate in the carbon rich storage lagoon.

Soluble carbonaceous biochemical oxygen demand data should be compiled to further investigate how biologically available the carbon in the recirculated flush water is for denitrification. If the biodegradable carbon is found to be limiting under the current operational regime or after operational adjustments are made, adaptations to the system process train could be made to introduce fresh, carbon-rich influent to nitrified water. The potential for clogging of the ReCip media bed should be considered for this intervention.

Research using multiple smaller ReCip units is beginning at Cal Poly currently. These studies will allow for controlled experiments on loading, reciprocation pattern, and media type. Future research should study alternative substrates to rock aggregate in order to potentially reduce capital costs. Alternates may include recycled concrete, plastic, and geotextile fabric.

Frequent sampling should be performed over the course of multiple weeks to analyze if average daily temperature influences influent TAN and/or effluent $\mathrm{NO}_{3}{ }^{-}$. Seasonal temperature variation over the course of a year can be used to reassess the 
accuracy of both the non-temperature and temperature dependent TAN removal models. Seasonal variations in influent and effluent water quality can also be assessed following one year of system operation and water quality analysis. Additional air quality

monitoring should be performed to analyze gas emissions from both the treatment system and the influent and effluent water. Air emissions should be compared to those of other wastewater treatment technologies and of croplands fertilized with manure. Finally, continued sludge monitoring can determine if accumulation has an impact on treatment performance and effluent water quality. 


\section{References}

Ahn, J.H., Kim, S., Park, H., Rahm, B., Pagilla, K., Chandran, K., 2010. $\mathrm{N}_{2} \mathrm{O}$ emissions from activated sludge processes, 2008-2009: Results of a national monitoring survey in the United States. Environ. Sci. Technol. 44, 4505-4511.

American Public Health Association (APHA), 2005. Standard Methods for the Examination of Water and Wastewater, 21st ed. American Public Health Assoc., American Water Works Assoc., and Water Environment Fed., Washington, DC.

Behrends, L.L., Coonrad, H.S., Bailey, E., Bulls, M.J., 1993. Oxygen diffusion rates in reciprocating rock biofilters: potential applications for subsurface flow constructed wetlands. In: Proceedings Subsurface Flow Constructed Wetlands Conference, University of Texas at El Paso.

Behrends, L.L., Sikora, F.J., Coonrad, H.S., Bailey, E., Bulls, M.J., 1996. Reciprocating subsurface-flow wetlands for removing ammonia, nitrate, and chemical oxygen demand: potential for treating domestic, industrial and agricultural wastewater. In: Proceedings Water Environment Federation, Dallas, Vol. 5, 251-263.

Behrends, L.L., 1999. Reciprocating subsurface-flow wetlands for improving wastewater treatment. U.S. Patent 5,863,433, January 1999.

Behrends, L.L., Houke, L., Bailey, E., Jansen, P., and Brown, D., 2001. Reciprocating constructed wetlands for treating industrial, municipal and agricultural wastewater. Water Sci. Technol. 44 (11-12), 399-405. 
Behrends, L. L., Bailey, E., Ellison, E., Houke, L., Jansen, L., Shea, P., Smith, C., and Yost, T., 2003. Reciprocating constructed wetlands for treating high strength anaerobic swine lagoon wastewater. In: Ninth International Symposium on Animal, Agriculture and Food Processing Waste, Durham, North Carolina.

Behrends, L. L., Bailey, E., Jansen, P., Houke, L., and Smith, S., 2008. Integrated constructed wetland systems: design, operation, and performance of low-cost decentralized wastewater treatment systems. In: Seventh International Water Association Specialty Conference on Small Water and Wastewater Systems, Mexico City.

Crites, R., Tchobanoglous, G., 1998. Small and Decentralized Wastewater Management Systems. McGraw-Hill, New York.

Halling-Sørensen, B., Jørgensen, S.E., 1993. The Removal of Nitrogen Compounds from

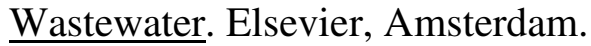

Kadlec, R.H., Knight, R.L., 1996. Treatment Wetlands. CRC Press, Boca Raton, Florida.

Leonard, K.M., Key, S.P., Srikanthan, R., 2003. A comparison of nitrification performance in gravity-flow and reciprocating constructed wetlands. Water Pollution VII: Modeling, Measuring, and Prediction, 293-301.

McKinsey, 2006. Foundations for a consumer-driven dairy growth strategy, Parts $1 \& 2$. Prepared for the California Milk Advisory Board by McKinsey and Co., pp.130.

Moss, L., 2007. Concentrated animal feeding operation (CAFO) regulation at federal and select state levels. Water Practice, 1(4), pp.11. 
National Resource Conservation Service (NRCS), 1992. Animal Waste Management Field Handbook: National Engineering Handbook Part 651. In: Agricultural Waste Management Field Handbook, U.S. Department of Agriculture, Chap. 4 \& 9.

Nelson, K.L., Jimenez, B., Tchobanoglous, G., Darby, J.L., 2004. Sludge accumulation, characteristics, and pathogen inactivation in four primary wastewater stabilization ponds in central Mexico. Water Res. 38(1), 111-127.

Rice, M., Humenik, F., 2004. Solids separation-reciprocating wetland. In: Development of Environmentally Superior Technologies: Phase I Report for Technology Determinations per Agreement Between the Attorney General of North Carolina and Smithfield Foods, Premium Standard Farms and Frontline Farmers, pp. 12.

San Joaquin Valley Dairy Manure Technology Feasibility Assessment Panel (SJVP), 2005. An Assessment of Technologies for Management and Treatment of Dairy Manure in California's San Joaquin Valley, pp. 212.

Spierling, R.E., Albinger, L.C., Lundquist, T.J., 2009. Projected performance and costs of wastewater treatment at California flush dairies. Final report, USEPA, Region 9, Award No. EP089000064.

United States Department of Agriculture (USDA), 2008. Manure and Byproduct Utilization, Agricultural Research Service, pp. 77.

United States Environmental Protection Agency (USEPA), 1993. Subsurface Flow Constructed Wetlands for Wastewater Treatment: A Technology Assessment, pp. 87. 
United States Geological Survey, 1986. Techniques of Water-Resources Investigations of the United States Geological Survey, Fluorometric Procedures for Dye Tracing, Ch. Al2, pp.34. 


\section{APPENDICES}

\section{APPENDIX A: Detailed Methods}

Suspended Solids

Total suspended solids (TSS) and volatile suspended solids analysis was conducted according to APHA Method $2540 \mathrm{D}$ and E, respectively. Prewashed and ashed $1.2 \mu \mathrm{m}$

G4 glass fiber filters (Fisher Scientific) were used for analysis. Duplicates, splits, and a TSS standard were used for quality control.

\section{Biochemical Oxygen Demand}

Total, carbonaceous, and nitrogenous 5-day biochemical oxygen demand testing was conducting according to APHA Method 5210 B. Dilution water was prepared with Hach BOD Nutrient Buffer Pillows. For $\mathrm{CBOD}_{5}$, Hach Nitrification Inhibitor Formula 2533 was used. Standards, prepared using Hach BOD Standard Solution for Dilution Method, and blanks were analyzed with each batch of samples.

\section{Total Ammoniacal Nitrogen}

Total ammoniacal nitrogen analysis was conducted per APHA Method 4500- $\mathrm{NH}_{3} \mathrm{D}$ (Ammonia-selective electrode method). Five point calibration curves were employed, ranging from 1-2500 mg/L NH 3 . Matrix spikes and splits were analyzed for quality control.

\section{Ion Chromatograph}

Nitrite and nitrate $\left(\mathrm{NO}_{2}^{-} / \mathrm{NO}_{3}^{-}\right)$were analyzed using a Dionex DX 120 Ion Chromatograph with the following setup (all parts manufactured by Dionex):

- IONPAC AS22 Analytical Column 
- IONPAC AG22 Guard Column

- DS4-1 Detection Stabilizer

- SRS 300 Self-Regenerating Suppressor

- AS40 Autosampler

Elluent was prepared with Grade 1 deionized (DI) water and contained $4.5 \mathrm{mM}$ and 1.4 $\mathrm{mM}$ of sodium carbonate and sodium bicarbonate, respectively. The elluent was degassed for 30 minutes using ultra high purity helium. The ion chromatograph was supplied with ultra high purity helium at a pressure of $60 \mathrm{psi}$, with an internal pressure reading between 2300 and 2500 psi. Elluent flow rate was maintained at $1.20 \mathrm{~mL} / \mathrm{min}$ and allowed to run for at least one hour prior to any analysis of samples. Four point calibration curves ranging from $0.20-20.30 \mathrm{mg} / \mathrm{L} \mathrm{NO}_{2}-\mathrm{N}$ and $0.16-16.48 \mathrm{mg} / \mathrm{L} \mathrm{NO}{ }_{3}-\mathrm{N}$ were prepared for each batch of samples using Dionex Seven Anion Standard II. Samples were filtered through $0.22-\mu \mathrm{m}$ Millipore Express PLUS ${ }^{\circledR}$ membrane filters, diluted by a factor of five, and placed into $5 \mathrm{~mL}$ Dionex poly vials and caped with Dionex $20 \mu \mathrm{m}$ filter caps. A matrix spike using the standard and sample splits were analyzed in addition to periodic standard splits to account for any timing drift in the chromatography. Additionally, DI water rinses of the injection needle were performed after each sample and DI blanks were analyzed prior to and after sample set to ensure no background noise existed prior to sample analysis.

\section{Organic Carbon}

Non-purgeable organic carbon and dissolved non-purgeable organic carbon (DNPOC) was analyzed using a Shimadzu TOC-V CSH Total Organic Carbon Analyzer. The machine sparges each sample, thereby removing inorganic carbon and volatile organic 
carbon. The sample was then combusted and the resulting $\mathrm{CO}_{2}$ detected through a gas analyzer. Five point calibration curves ranging from $50-500 \mathrm{mg} / \mathrm{L}$ were constructed prior to each run and samples were diluted by a factor of ten. For DNPOC, samples were filtered through 0.45- $\mu \mathrm{m}$ Millipore Express PLUS ${ }^{\circledR}$ membrane filters. Blanks, standard splits, matrix spikes, and sample splits were analyzed for quality control.

\section{Total Nitrogen}

Total nitrogen (TN) and dissolved total nitrogen (DN) was analyzed using the Shimadzu TOC-V CSH Total Organic Carbon Analyzer with a supplemental Shimadzu TNM-1 Total Nitrogen Measuring Unit. Like NPOC analysis, each sample was combusted in the TOC analyzer. However for TN/DN analysis the resulting gas from combustion was analyzed by the supplemental TNM unit, where nitrogen monoxide is detected. Five point calibration curves ranging from $25-200 \mathrm{mg} / \mathrm{L}$ were constructed prior to each run and samples were diluted by a factor of ten. For DN, samples were filtered through 0.45 $\mu \mathrm{m}$ Millipore Express PLUS ${ }^{\circledR}$ membrane filters. Blanks, standard splits, matrix spikes, and sample splits were analyzed for quality control.

\section{Alkalinity}

Alkalinity of samples was determined per APHA Method 2320 B (Titration Method). Temperature and Dissolved Oxygen Temperature and dissolved oxygen of samples were measured on site immediately after sampling to ensure accuracy. 


\section{Flow Rate}

Flow rate of the influent pump was measured each week during sampling to monitor the hydraulic residence time of the system. A calibrated five gallon bucket and a stopwatch were used to determine the flow rate (gpm) of the influent. 


\section{APPENDIX B: Supplemental Data}

\section{B.1 Tracer Studies}

The following (Table B.1 and Figures B.1, B.2) are provided to further detail the tracer studies discussed in Sections 2.3 and 3.2.1. Sump samples were taken from the sump in Basin 2. Rhodamine WT concentration was determined using separate calibration curves for each study. Background fluorescence of influent water, sump samples, and effluent samples was noted and accounted for in any calculations of residence time. Recall that although both studies utilize the same reciprocation schedule and water volumes in the system, the September 2009 study was performed with tap water prior to the introduction of lagoon water and the June 2010 study used lagoon water after seven months of operation.

Table B.1. Summaries of Rhodamine WT fluorescent dye tracer studies. Calculated MHRT based on estimation of time for $50 \%$ of dye to exit system based on extrapolations of effluent concentration decay.

\begin{tabular}{llll}
\hline & Units & Sept 2009 & June 2010 \\
\hline Input solution volume & $\mathrm{mL}$ & 10 & 20 \\
Actual dye volume & $\mathrm{mL}$ & 2 & 4 \\
Density of dye & $\mathrm{g} / \mathrm{mL}$ & 1.19 & 1.19 \\
Actual mass of dye & $\mathrm{G}$ & 2.38 & 4.76 \\
\hline Dye exiting system & $\mathrm{G}$ & 1.08 & 1.25 \\
Percent dye exiting & $\%$ & 45 & 26 \\
Percent dye attenuated & $\%$ & 55 & 74 \\
\hline THRT & Day & 7 & 4.4 \\
MHRT & Day & 2.9 & 1.8 \\
MHRT-to-THRT ratio & - & 0.42 -to-1.0 & 0.42 -to-1.0 \\
\hline
\end{tabular}




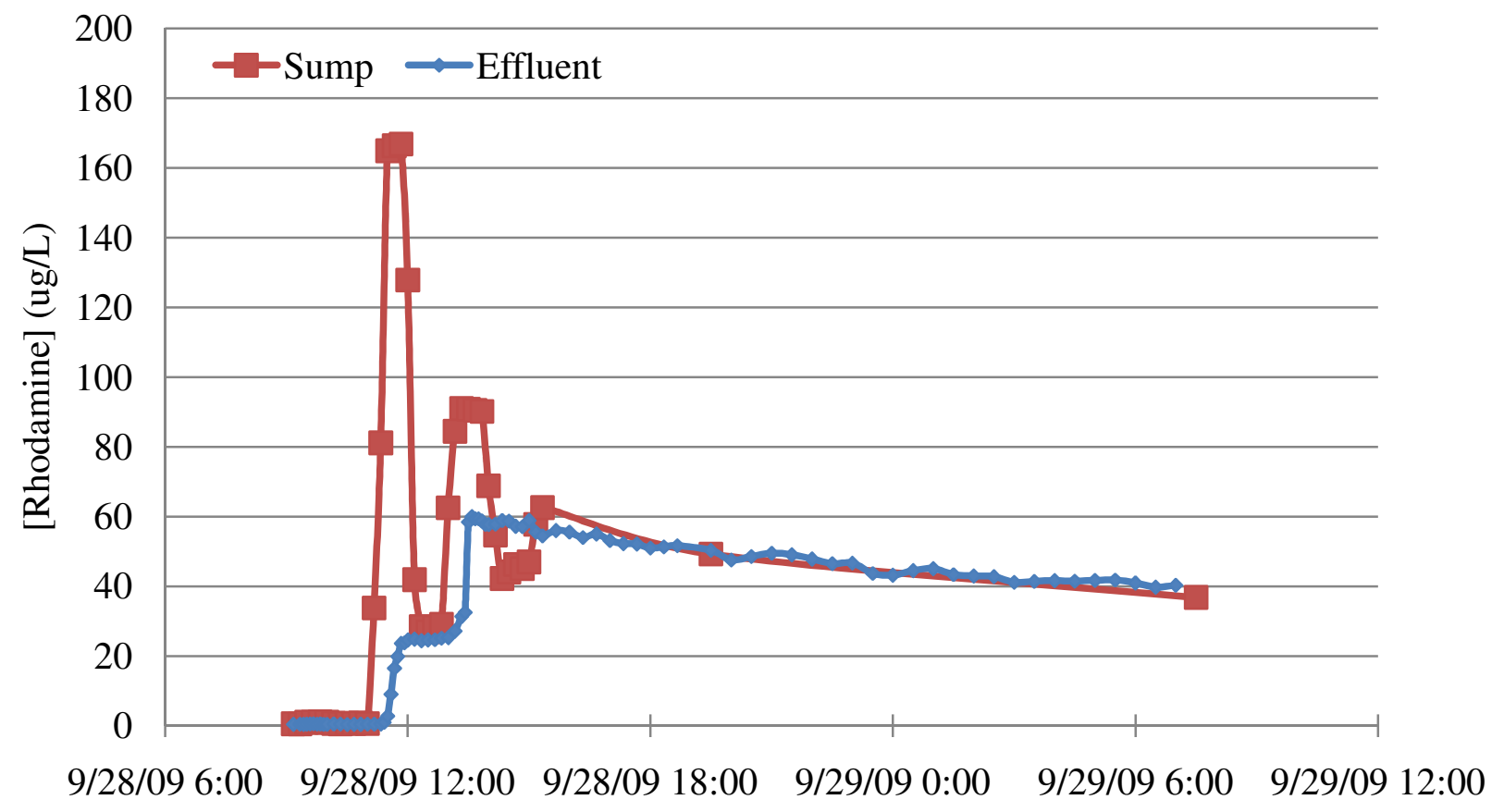

Figure B.1. September 2009 tracer study data. Oscillation of Rhodamine WT dye concentration in sump shows effect of reciprocation. 


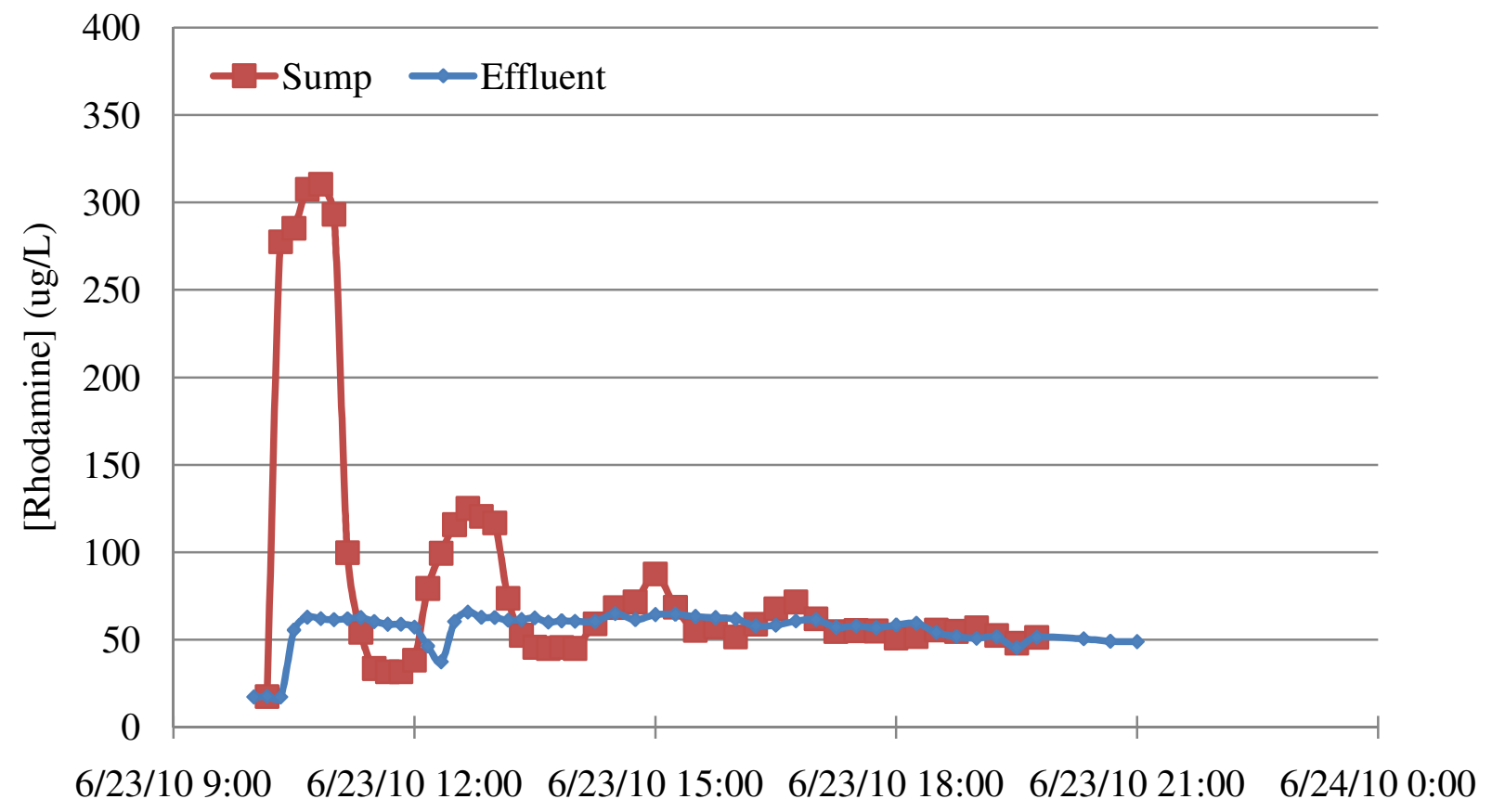

Figure B.2. June 2010 tracer study data. Note similar oscillation and increased concentrations due to increased input mass of Rhodamine WT dye in comparison to Figure B.1.

\section{B.2 Settleable Solids}

Settleable solids were be monitored on a monthly basis (Table B.2). Perhaps a relationship between sludge accumulation and influent settleable solids can be determined. Effluent settleable solids data may also provide insight into the treatment performance of the system. 
Table B.2. Settleable solids data. Measured using 1-L Imhoff cone after one hour of settling.

\begin{tabular}{lll}
\hline \multirow{2}{*}{ Date } & Influent & Effluent \\
\cline { 2 - 3 } & $(\mathrm{mL} / \mathrm{L})$ & $(\mathrm{mL} / \mathrm{L})$ \\
\hline 7-Apr-10 & 1.3 & 0.0 \\
6-May-10 & 2.0 & 0.0 \\
10-Jun-10 & 2.0 & $<0.1$ \\
\hline
\end{tabular}




\section{APPENDIX C: Photos}

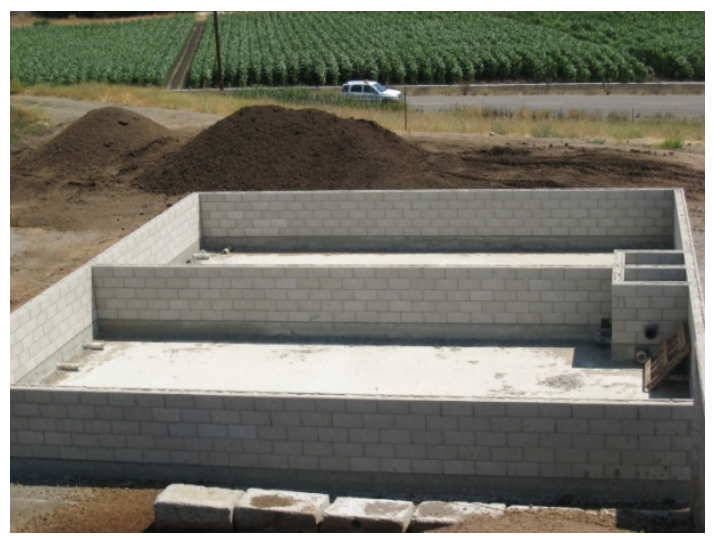

Figure C.1. Completed, empty basins. View from solids separation screen.

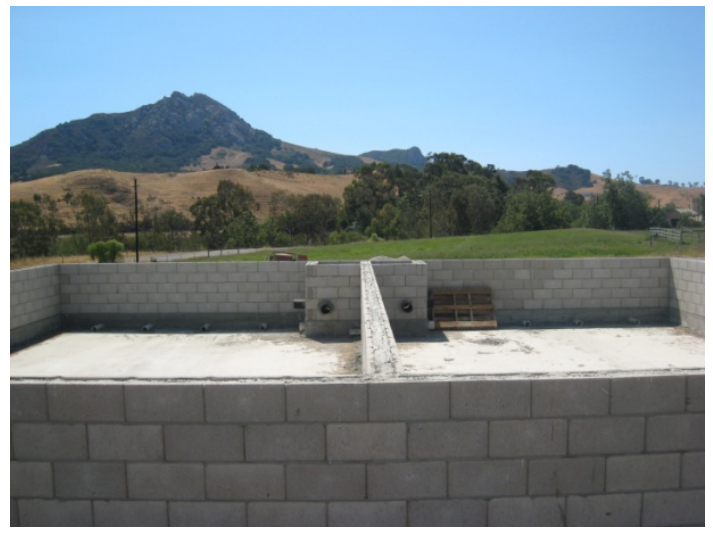

Figure C.2. View of completed basins from ground level.

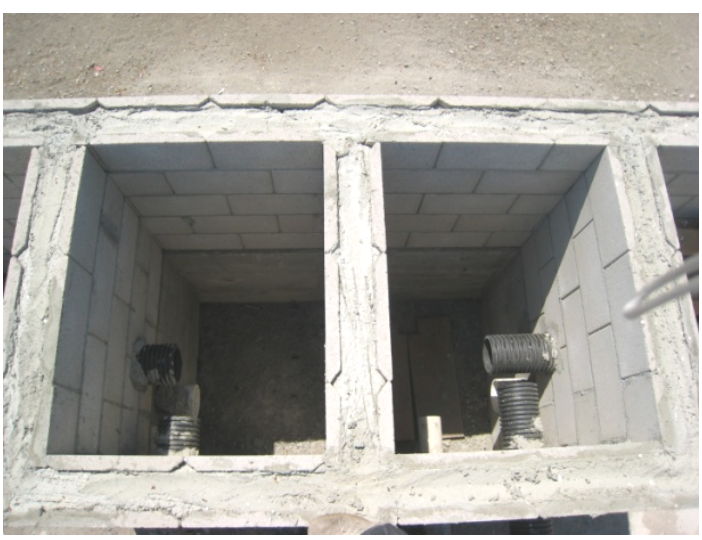

Figure C.3. Sumps with pipe penetrations. Black perforated pipes assist in draining basins, white pipe in right sump is connected to weir box in Basin 2.

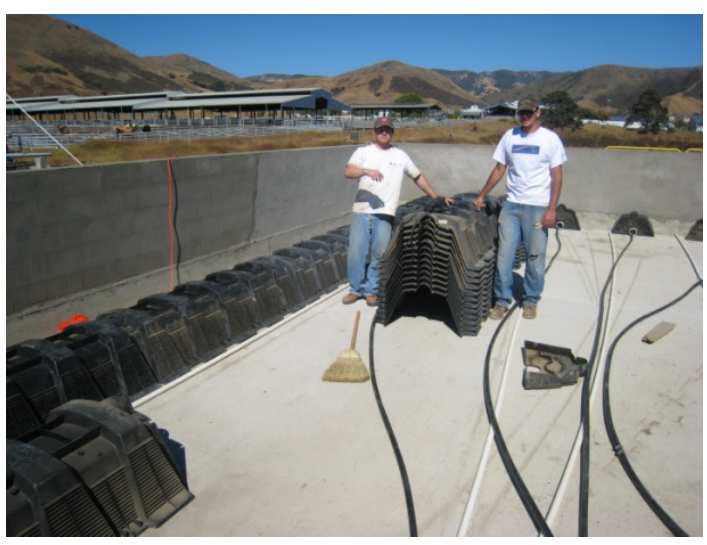

Figure C.4. Installation of Biodiffuser leach field chambers. Black and white pipes will run along floor and connect to aerator manifold. Black pipes lie underneath chambers, white pipes lie between chambers. 


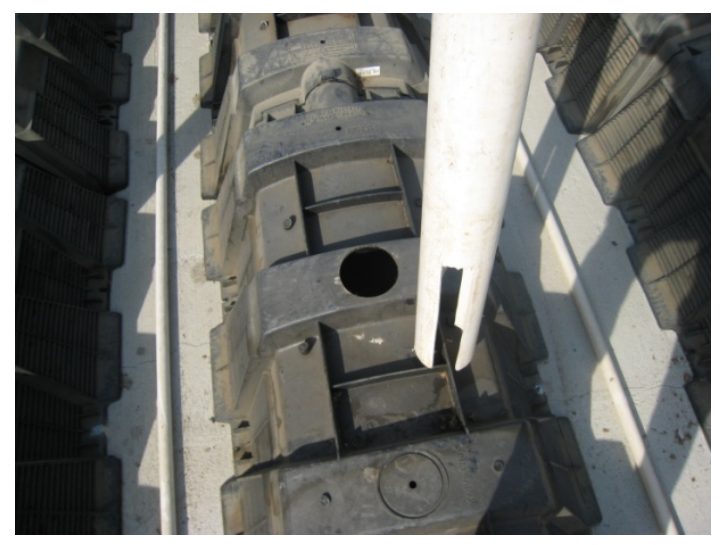

Figure C.5. Installation of standpipes into leach field chambers. Slots in pipe leave room for black aeration pipes lying on basin floor.

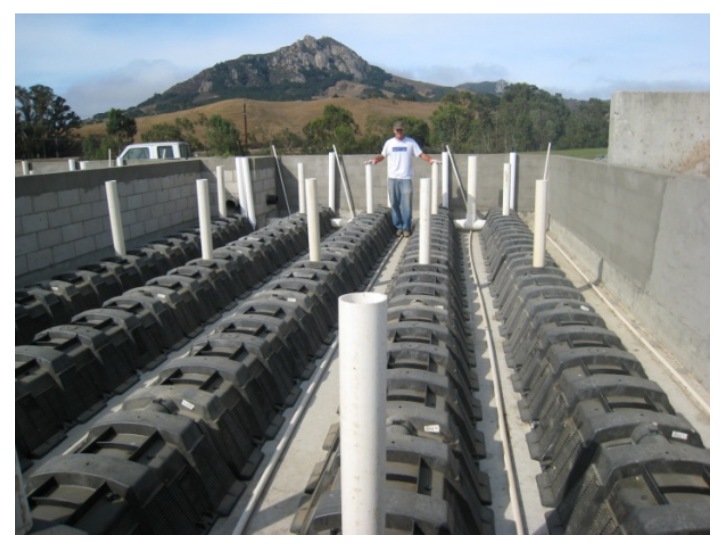

Figure C.6. Completed leach field chamber installation. Three standpipes in each chamber row.

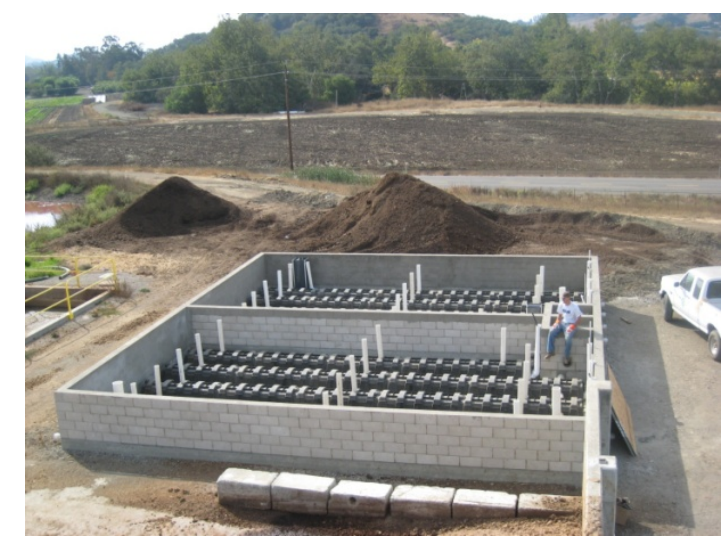

Figure C.7. View of leach field chamber network from solid separation screen.

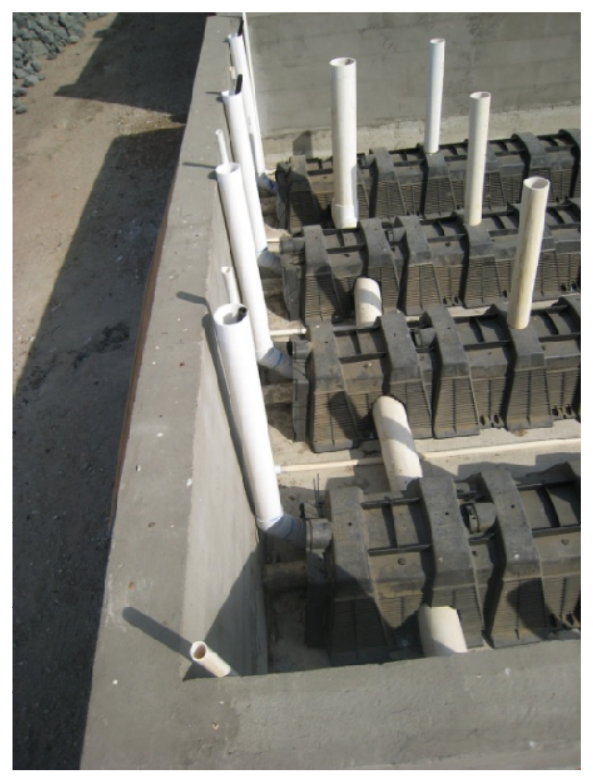

Figure C.8. Leach field chamber network along western wall. Large white pipes along wall house black aeration tubes running up from underneath chambers. Small white pipes along wall are aeration pipes running between chambers. Large white pipe sections connecting chambers help drain basin. 


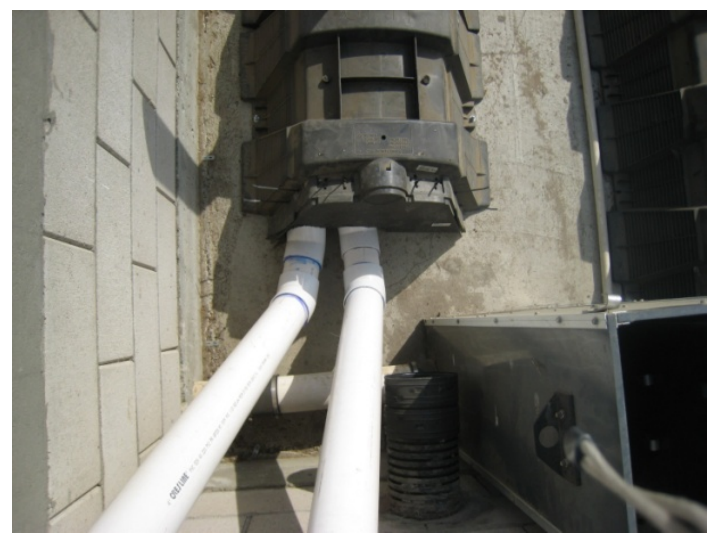

Figure C.9. Weir box in south tank near sump. Controls water level in north tank. Pipe on floor connects weir box to Basin 1.

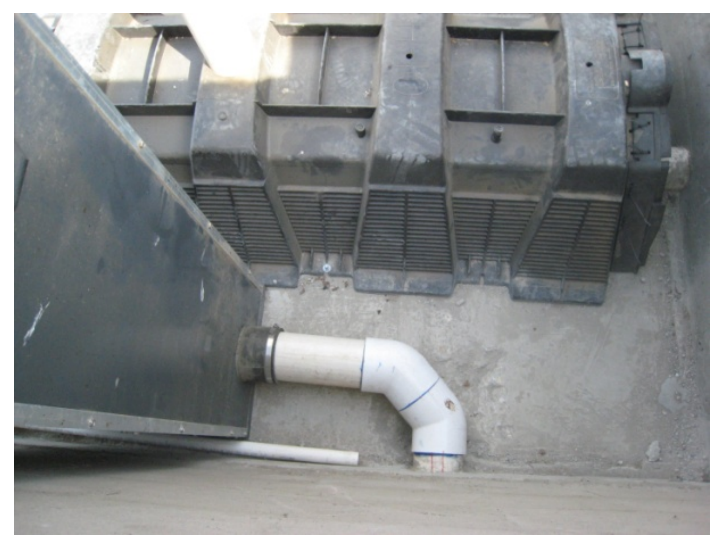

Figure C.10. Effluent pipe connecting to effluent weir.

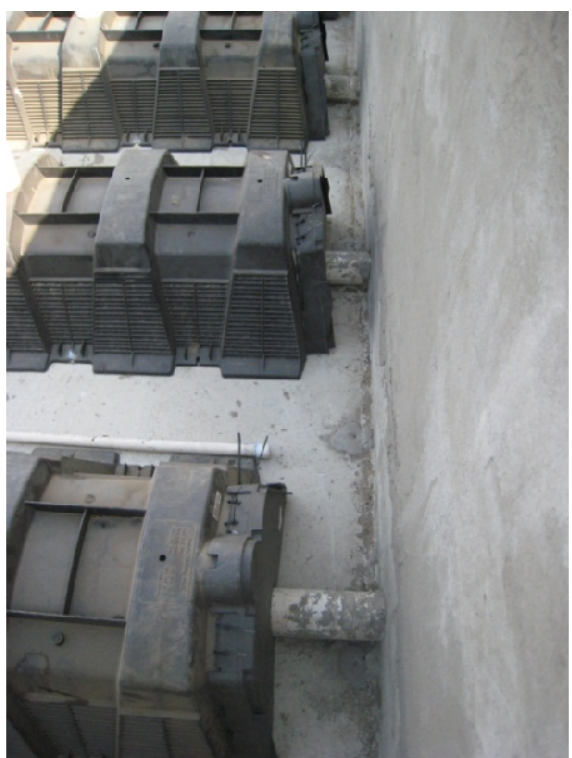

Figure C.11. Pipe penetrations connecting leach field chambers to outside of basins. Extend approximately $30-\mathrm{cm}$ into chamber and provide conduit for sludge removal.

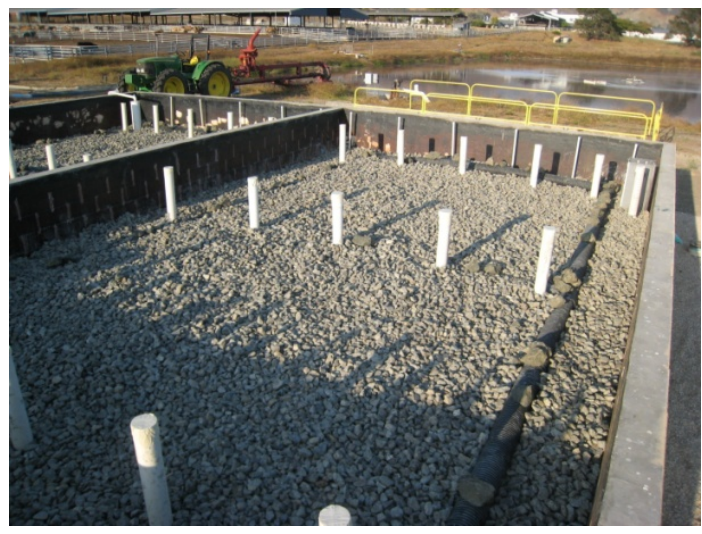

Figure C.12. Basin 2 after installation of two rock layers. Black perforated pipe network, installed to assist drainage. 


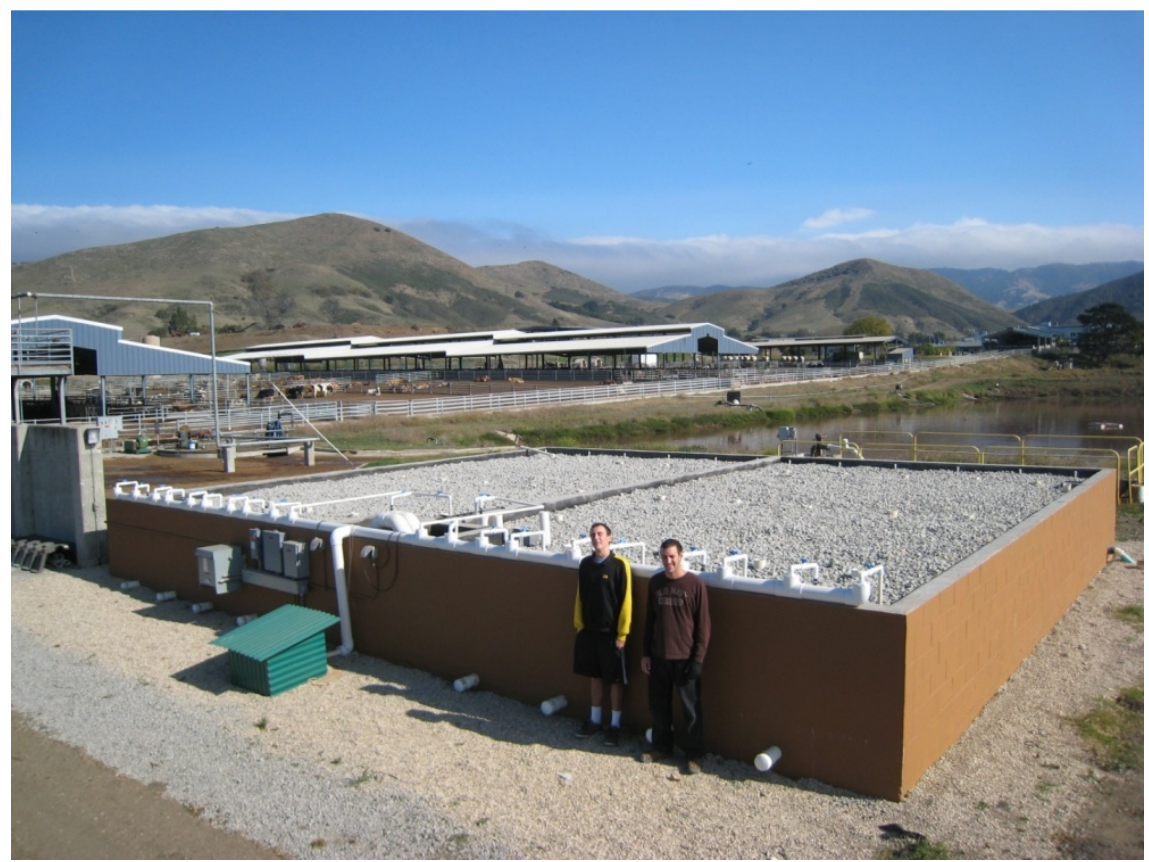

Figure C.13. Completed ReCip system. Aeration manifold installed on near wall connecting aeration piping to blower, housed in small green shed in foreground. 